$3-5-2012$

\title{
Constitutional Rights And The Problem Of Legal Authority
}

Christopher J. Peters

University of Baltimore School of Law, cpeters@ubalt.edu

Follow this and additional works at: http://scholarworks.law.ubalt.edu/all_fac

Part of the Law Commons

\section{Recommended Citation}

Christopher J. Peters, Constitutional Rights And The Problem Of Legal Authority, (2012).

Available at: http://scholarworks.law.ubalt.edu/all_fac/869

This Article is brought to you for free and open access by the Faculty Scholarship at ScholarWorks@University of Baltimore School of Law. It has been accepted for inclusion in All Faculty Scholarship by an authorized administrator of ScholarWorks@University of Baltimore School of Law. For more information, please contact snolan@ubalt.edu. 
Submission version 1 - last revised 3/5/2012

CONSTITUTIONAL RIGHTS

AND THE PROBLEM OF LEGAL AUTHORITY*

\author{
Christopher J. Peters ${ }^{\dagger}$
}

This article responds to a puzzling gap in the otherwise extensive literature on constitutional rights and judicial review: a lack of attention to the authority of constitutional rights. Defenders and critics of judicially enforceable constitutional rights typically argue on grounds of political morality, contending that democratic legal systems should (or should not) adopt constitutional rights as a matter of policy. That issue becomes irrelevant if the subjects of constitutional rights - government officials, legislators, judges, citizens - have little or no good reason to obey those rights. This is a question of legal authority; but most treatments of constitutional rights ignore it.

The article begins to fill that gap by assessing the two dominant strains of rights-justification, Substantive and Procedural justifications, as accounts of legal authority. Substantive justifications defend constitutional rights as means of promoting morally good results; prominent theories from Alexander Hamilton's to Alexander Bickel's to Randy Barnett's are types of Substantive account. The author argues that Substantive justifications, while intuitively appealing and therefore common in public and political discourse, fail to persuasively explain the necessary authority of constitutional rights. In contrast, Procedural justifications defend constitutional rights as means of settling disputes about good results; the "representationreinforcement" approach of John Hart Ely and Carolene Products Footnote Four is the best-known Procedural account. The article contends that Procedural justifications fare considerably better than their Substantive rivals as accounts of constitutional authority. In short, people have better reasons to obey constitutional rights on the Procedural approach - a considerable point in its favor, to say the least.

\footnotetext{
* C Christopher J. Peters. All rights reserved. Please do not cite or quote this draft without the author's express permission.

$\dagger$ Professor of Law, University of Baltimore School of Law.
} 
I. INTRODUCTION: RIGHTS-JUSTIFICATIONS AND THE OVERLOOKED QUESTION OF LEGAL AUTHORITY ............................. 4

II. THE CONCEPT OF LEGAL AUTHORITY...................................... 8

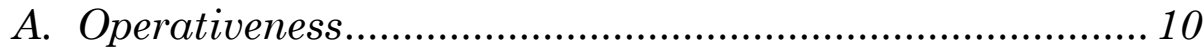

B. Special Force ……...................................................... 13

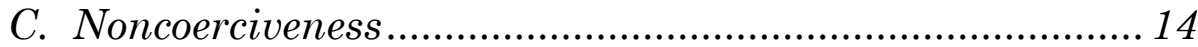

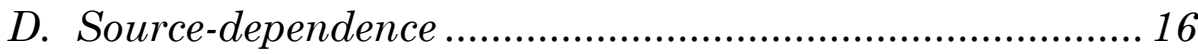

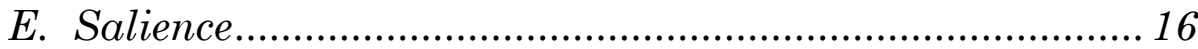

F. A Note on the Identity of the Legal Subject in Debates about Constitutional Rights ..................................................21

III. SubSTANTIVE JUSTIFICATIONS AS ACCOUNTS OF LEGAL

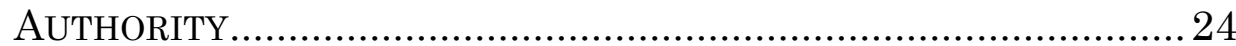

A. Substantive Justifications: The Simple Version ............. 24

1. Operativeness (and Special Force, Noncoerciveness, and

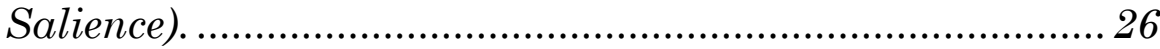

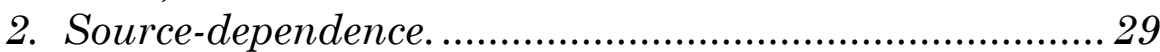

B. Substantive Justifications: The Nuanced Version ........... 30

1. The idea of a comparative decisional advantage............ 33

2. The classic Hamiltonian account as a type of Nuanced

Substantive Justification....................................................... 35

C. A More-nuanced Look at the Nuanced Version ................. 38

1. Salience (Part I) ............................................................ 38

2. Salience (Part II) ............................................................ 43

3. The Aristotelian Difficulty (Part I)............................... 45

4. The Aristotelian Difficulty (Part II).............................. 52

IV. Procedural Justifications as AcCounts of LEGAL

AUTHORITY (WITH SPECIAL ATTENTION TO "REPRESENTATION-

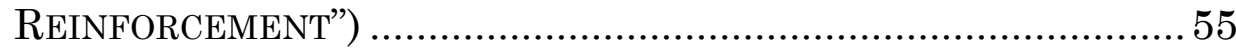

A. Representation-Reinforcement as a Procedural

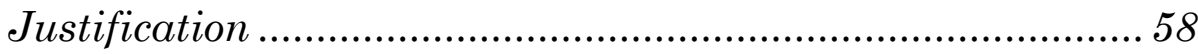

B. Hamiltonian Accounts as Procedural Justifications ....... 64

C. Representation-Reinforcement and Legal Authority .........66 66

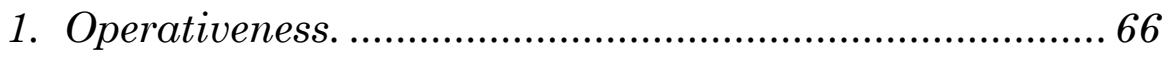

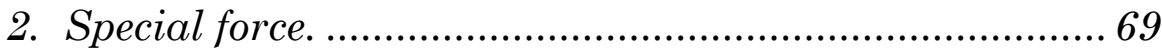

3. Noncoerciveness.. ......................................................... 71

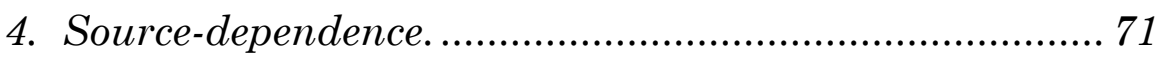

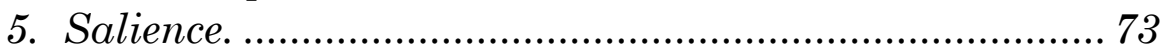

V. Conclusion: FleEIng Substance …………….................. 79 
Submission version 1 - last revised 3/5/2012

\title{
CONSTITUTIONAL RIGHTS AND THE PROBLEM OF LEGAL AUTHORITY*
}

\author{
Christopher J. Peters ${ }^{\dagger}$
}

[T] his country's original citizens believed that as human beings, they were entitled to free speech, and they invented the First Amendment in order to protect it. The entire Bill of Rights was created to protect rights the original citizens believed were naturally theirs ....

\section{From the ACLU website ${ }^{1}$}

The Declaration of Independence makes clear that the purpose for writing the Constitution was twofold. It was written to grant the federal government the authority to impose upon specific liberties in order to protect the natural rights of citizens; it was also written to protect the rights of citizens from both the overreaching hand of government and outside oppressors.

\section{From the Freedom Works website ${ }^{2}$}

\footnotetext{
* ( C) Christopher J. Peters. All rights reserved. Please do not cite or quote this draft without the author's express permission.

$\dagger$ Professor of Law, University of Baltimore School of Law.

1 ACLU, The Bill of Rights: A Brief History, available at http://www.aclu.org/racial-justice_prisoners-rights_drug-law-reform_immigrantsrights/bill-rights-brief-history.

${ }^{2}$ Matthew Clemente, The Constitutionality of Obama's Mandate: Reading the Constitution (2 of 8), available at http://www.freedomworks.org/blog/mclemente/theconstitutionality-of-obamas-mandate-reading-th. The "mission" of FreedomWorks, according to its website, is to "fight[] for lower taxes, less government and more economic freedom for all Americans," see http://www.freedomworks.org/about/ourmission; the organization's chairman is former Republican House majority leader Dick Armey, see http://www.freedomworks.org/about/chairman-dick-armey. The New York Times describes FreedomWorks as "a Washington group that helped cultivate the Tea Party movement." Michael Cooper and Katharine Q. Seelye, Wisconsin Leads Way as Workers Fight State Cuts, N.Y. Times (Feb. 18, 2011), available at http://www.nytimes.com/2011/02/19/us/politics/19states.html?scp=3\&sq=wisconsin\% 20cuts\&st $=$ cse.
} 
Courts must police inhibitions on expression and other political activity because we cannot trust elected officials to do so: ins have a way of wanting to make sure the outs stay out.

John Hart Ely3

\section{INTRODUCTION: \\ RIGHTS-JUSTIFICATIONS AND THE OVERLOOKED QUESTION OF LEGAL AUTHORITY}

$\mathrm{T}$ here are many good recent critiques, and at least as many good recent defenses, of the idea of constitutional rights. ${ }^{4}$ Both the critiques and the defenses almost always assume a particular audience, one consisting of what we might call institutional designers. Institutional designers are in a position either to invent or reinvent the governing institutions of a society (like, say, the American Framers in the 1780s or the post-Soviet and post-apartheid-South-African nationbuilders of the 1990s), or (far more often) to seriously reassess some of the governing institutions the society already has (as happened during recent debates in Great Britain and New Zealand over the adoption of statutory Bills of Rights). ${ }^{5}$ In

\footnotetext{
3 John Hart Ely, Democracy and Distrust: A Theory of Judicial Review 106 (1980)

4 The critiques include JEREMy WALDRON, LAW AND DisagreEMENT 209-312 (1999) (Part III); Jeremy Waldron, The Core of the Case Against Judicial Review, 115 YAle L.J. 1346 (2006) [hereinafter Waldron, Core Case]; and RichaRd Bellamy, Political Constitutionalism (2007). The defenses include W.J. Waluchow, A Common LaW Theory of Judicial Review: The Living Tree (2007); Ronald DWORKIn, Introduction: The Moral Reading and the Majoritarian Premise, in Freedom's LaW: The Moral Reading of the American Constitution 10-38 (1996); Christopher L. Eisgruber, Constitutional Self-Government (2001); Lawrence G. Sager, Justice in Plainclothes: A Theory of American Constitutional PRACTICE (2004); and Richard J. Fallon, Jr., The Core of an Uneasy Case for Judicial Review, 121 HARV. L. REV. 1693 (2008).

5 In Britain, the Human Rights Act of 1998 authorized direct enforcement in British courts of the provisions of the European Convention on Human Rights. See Human Rights Act, 1998, c. 42. In New Zealand, the Bill of Rights Act of 1990 authorized a weak form of judicial review by which judges must interpret other sta-
} 
speaking to institutional designers, rights-critics and rightsdefenders usually argue in terms of policy or political morality - of why it is or is not a good idea for a society to adopt some form of judicially enforceable constitutional or quasiconstitutional rights.

So situated, these debates typically miss a crucial question about constitutional rights, namely the question of whether (and under what conditions) constitutional rights can possess legal authority. In a nutshell, legal authority is the capacity of law to impose on its subjects a duty or strong reason to act, a duty that depends on the source of the norm in question, that does not depend on the threat of punishment for disobedience, and that is sufficiently salient to be perceived by the reasonable legal subject. Legal authority is necessary for legal systems generally to function, but it is especially important for constitutional rights. Without legal authority, no constitutional right would be effective - that is, would make much of a difference in the real world. Those typically subject to constitutional rights - elected or appointed government officials (particularly high-level ones), judges, and ultimately the democratic majority itself - rarely can be effectively punished for violating or ignoring them. Absent some perceived duty to obey constitutional rights, then, these actors often would simply disobey, and the rights in question would become dead letters - mere words on parchment, or on the twenty-first-century equivalent thereof.

Debates about constitutional rights that are directed at institutional designers tend to overlook the issue of legal authori-

tutes to avoid conflict, if possible, with the rights enumerated in the Act. See New Zealand Bill of Rights Act 1990, 1990 S.N.Z. No. 109. Although each of these "bills of rights" has the formal status only of an ordinary statute, subject to amendment or repeal through the regular legislative process, it seems clear that the practical obstacles to repeal have conferred on each Act a quasi-constitutional status. The Acts thus edge Britain and New Zealand closer to an American model of judicially enforceable constitutional rights. 
ty because it does not seem like a question of primary importance to their audience. Institutional designers create new legal systems or tweak existing ones; the assumption is that the legal systems thus created or tweaked will, generally speaking, be obeyed. But what if this were not the case? Then there would be no point in creating or tweaking the legal systems to begin with. Arguments about Bills of Rights and judicial review would take on a sort of counterfactual air, like alternatehistory novels about the South winning the Civil War (but less entertaining). They would become academic in the driest and least productive sense.

It seems fairly clear, of course, that the participants in these debates are correct to assume that constitutional rights (generally speaking) are treated, or would be treated if adopted, as carrying legal authority in most or all of the societies in play. The question I want to explore in this article, then, is not whether constitutional rights can or typically do possess legal authority. My question, rather, is what the overlooked question of legal authority might tell us about these normative debates over constitutional rights. In particular, I want to ask whether any of the chief defenses of constitutional rights that have been advanced can adequately account for their legal authority - can adequately explain how constitutional rights, so defended, are capable of imposing the kind of duty or strong reason for obedience that legal authority requires. If the answer is no - if none of the influential rights-justifications can explain the legal authority of Bills of Rights - then the rightscritics will have a new and effective, perhaps even fatal, arrow in their quiver. (What is the point of constitutional rights that no one has a duty to obey?) On the other hand, if the answer (as I will in fact suggest) is that some rights-justifications can explain legal authority better than others, then the rightsdefenders can toss out the blunt arrows and concentrate on firing the good ones. 
In order to engage the question of legal authority we need to focus on the perspective, not of the institutional designer, but of the legal subject - the person, or the institution or collection of persons, who is faced with the decision whether to do what a constitutional right commands (or, more typically, to refrain from doing what it forbids). This is precisely the perspective that the normative debate over constitutional rights usually ignores. But it is the locus where the results of that debate must be operationalized, the contact point where the constitutional rubber meets the road. If the legal subject (the legal official, the legislator, the judge, the voter) is simply going to ignore constitutional rights, then having constitutional rights is neither good nor bad, essential nor catastrophic; it is at most a waste of time.

This paper therefore uses the perspective of the subject of constitutional rights to assess the possible grounds on which those rights can claim legal authority. I argue that one family of rights-justifications, which I call Substantive justifications, fails to offer legal subjects a good-enough, strong-enough reason to obey constitutional rights with which they disagree. The basic assertion of Substantive justifications is this: Constitutional rights should be obeyed because (and to the extent that) they will lead us to a morally correct or optimal or desirable result. The first two quotations that open this paper - from two organizations that could hardly be more opposed on most topics of political morality - exemplify versions of Substantive justifications. As these quotes suggest, Substantive justifications are, in a simple form, fashionable in political and popular discourse; in a more nuanced form they are common in academic theory. But they are flawed, perhaps fatally so, as accounts of legal authority. Or so I will argue.

I also contend that a rival type of rights-justification, which I call a Procedural justification, fares much better as an explanation of legal authority: It confers upon legal subjects some- 
thing like a prima facie duty of obedience to constitutional rights. Procedural justifications contend that constitutional rights should be obeyed because (and to the extent that) obedience helps avoid or mitigate or resolve certain kinds of disputes. The third quotation above, from John Hart Ely's justly influential Democracy and Distrust, illustrates a type of procedural justification. While Ely's and related versions of Proceduralism lack the widespread popular appeal of their Substantive rivals, they constitute the chief alternative to Substantivism within judicial practice and academic theory. I will suggest here that they have a significant advantage over their Substantive counterparts as accounts of the legal authority of constitutional rights.

The paper proceeds as follows. In Part II, I articulate an understanding of the concept of legal authority, one derived from (though perhaps not entirely coextensive with) the standard accounts. In Part III, I flesh out two versions of the Substantive justification - a simple and a more-nuanced version and assess them according to the components of legal authority identified in Part II, finding them wanting in a number of important respects. In Part IV, I give the same treatment to Procedural justifications (using Ely's version as a framework), but with more sanguine results. Part V is a brief conclusion.

\section{The CONCEPT OF LEGAL AUTHORITY}

The idea of legal authority is among the most complex and elusive concepts in legal philosophy; given its centrality to the law, surprisingly few elements of the concept can be considered settled. ${ }^{6}$ Many aspects of this debate are, thankfully, well beyond my focus here. I will try to sketch, at a middling level of detail, a basic version of the concept that will allow us to as-

\footnotetext{
${ }^{6}$ For a summary of the debate that also stakes out a provocative position in it, see Scott J. Shapiro, Authority, in The OxFord HandbooK of JuRISPRUdence \& Philosophy of LAW 382-439 (Jules Coleman \& Scott Shapiro eds., 2002).
} 
sess the competing rights-justifications in a meaningful way. While I believe the substance of the concept as I describe it here is fairly standard, my terminology sometimes will not be; so I will try to be careful in defining my terms and in crossreferencing more common ones where appropriate.

It will help to begin with a fairly straightforward illustration of legal authority at work, taken from the context of constitutional rights in deference to the central focus of this paper. Suppose George, the chief executive of a contemporary Western democracy, is asked by his national-security advisors to authorize intelligence agencies to conduct electronic surveillance of terrorism suspects without obtaining judicial search warrants. And suppose George believes that authorizing the warrantless surveillance would be the morally best thing to do, taking account of all the relevant nonlegal factors. But suppose George's legal advisors tell him that the warrantless surveillance he is contemplating would violate a provision of their nation's constitution that has been interpreted to prohibit certain kinds of searches without a judicially issued warrant. If George believes this constitutional provision (as interpreted) is legally authoritative - that is, that it possesses valid legal authority - he will take its existence as a very powerful reason not to authorize the surveillance, despite his belief that the surveillance would, absent the law, be the morally best course of action. (Even if George attributes legal authority to the constitutional provision, he still may ultimately decide to authorize the surveillance despite the constitutional prohibition against it; but at least he will recognize the existence of that

\footnotetext{
7 For instance, I will not use the common term "content-independent" to describe an essential feature (actually a combination of features, I believe) of legal authority. (For a typical account of the meaning of that term, see Shapiro, supra note 6, at 389.) I think the focus on whether it is the "content" of a norm that confers its normativity is misleading, as the concept of "content" is extremely vague, and because what usually is meant by "content-independence" seems to encompass a number of phenomena that have little or nothing to do with "content." See infra notes 16-20 and accompanying text.
} 
prohibition as a strong countervailing influence against his own unalloyed moral judgment.)

As this example reveals, legal authority has the potential to motivate a morally responsible actor to perform some action he otherwise would deem morally inappropriate, or to refrain from some action he otherwise would deem morally appropriate. But what are the properties of legal authority that confer this special capacity to change the existing moral landscape?

The illustration suggests at least five such properties, each of which I discuss in more detail below. First, legal authority supplies an operative reason to act, that is, a reason that actually alters the applicable moral calculus, serving as a reason to act, not just to believe something or think in a certain way. Second, legal authority supplies a reason to act that has special normative force, akin to that of a prima facie duty rather than a garden-variety reason for action. Third, the reason provided by legal authority is noncoercive: It does not turn on the threat of some formal sanction for violating the relevant norm. Fourth, that reason is source-dependent: Its special status depends on the derivation of the norm in question. And fifth, the reason is salient, in the sense that its possession of the other necessary properties of legal authority is readily apparent to a reasonable legal subject.

\section{A. Operativeness}

An authoritative legal norm must supply a reason that is operative, that is, a reason to act that alters the applicable balance of reasons rather than simply affecting the way a legal subject assesses those reasons. ${ }^{8}$

\footnotetext{
8 The relevant distinction here often is referred to as the distinction between "a reason to act" and "a reason to believe," or between a "normative" and an "epistemic" reason. See, e.g., John Gardner \& Timothy Macklem, Reasons, in THE OxFORD HANDBOOK OF JURISPRUDENCE \& PHILOSOPHY OF LAW 440, 444 (2002).
} 
Consider here the distinction between a truly authoritative norm and a piece of mere advice or advocacy. Our hypothetical chief executive, in deciding whether to authorize warrantless electronic surveillance of terrorism suspects, will face many nonlegal reasons applicable to his decision, some favoring the surveillance (e.g., it would promote national security) and some opposing it (e.g., it would invade the privacy of some innocent persons). Now suppose that a trusted advisor, asked by George for her advice, counsels against the surveillance on the ground that it would impose too great a cost to personal privacy with relatively little benefit to national security. This advice may change the way George himself assesses the applicable reasons; it might cause him to scrutinize the alleged nationalsecurity benefits of the surveillance more carefully than he otherwise would have done, for example. But the advice is unlikely to change the balance of applicable reasons itself. George will not think that the advice creates some new reason to act that did not exist before the advice was given, or that the advice somehow alters the status of the existing reasons (by making the benefit to national security weaker than it would have been without the advice, for instance, or making the harm to personal privacy stronger). ${ }^{9}$

Now suppose George encounters a white paper by a civilliberties advocacy group, arguing against the type of surveillance being proposed as a serious threat to personal privacy. Again, the group's advocacy might change the way George assesses the applicable reasons for action - perhaps correcting some misconceptions he might otherwise have held, for example. But the advocacy (again) will not alter the balance of applicable reasons itself. George will not treat the advocacy as

\footnotetext{
9 Some have suggested that advice provides, or can provide, a new reason for acting in accordance with it. See, e.g., Stefan Sciaraffa, On Content-Independent Reasons: It's Not in the Name, 28 L. \& PHIL. 233 (2009). I am skeptical that this is accurate as a description of our practice; but even if it is, surely advice does not always, or necessarily, provide such a reason.
} 
creating some new reason to act or as affecting the status of the existing reasons.

An authoritative legal norm, however - say, the constitutional warrantless-search provision forbidding the surveillance - functions quite differently from these examples of advice and advocacy: It actually changes the previously existent set of reasons relevant to action. Imagine two parallel universes, identical in every respect except for the following: In Universe A there is no constitutional provision prohibiting the electronic surveillance George must consider, while in Universe B there is such a provision. Now imagine that George in Universe A, in the midst of deciding whether to authorize the surveillance, finds himself suddenly, magically transported to Universe B. What effect will the emergence of a legal norm forbidding the surveillance have on George's moral reasoning? Not that of mere advice or advocacy: The legal norm will not simply change the way George thinks about the balance of reasons for action. Instead it will change that balance of reasons itself; it will add a new reason to the mix, one that did not exist without the legal norm. ${ }^{10}$

Another way to put this point is to note that authoritative legal norms provide reasons to act, not just reasons to believe or to think about how to act. The advisor's counsel and the rights group's advocacy are intended to inform (and may have the effect of informing) George's own process of thinking about what he should do; but the constitutional provision is intended to motivate (and has the effect of motivating) his action itself, not just his process of thinking about it.

10 It might even alter the status of the existing reasons, by, for example, preempting them (see Joseph Raz, The Morality of Freedom 57-62 (1986)) or requiring that they be reweighted (see Stephen Perry, Second Order Reasons, Uncertainty, and Legal Theory, 62 S. CAL. L. REV. 913, 932-36 (1989); Stephen Perry, Judicial Obligation, Precedent and the Common Law, 7 OxFORD J. LEG. STUD. 215 (1987). See generally Shapiro, supra note 6, at 404-05, 408-12. 


\section{B. Special Force}

Legal philosophers debate the precise normative force and mechanics of the type of reason that is embodied in legal authority, ${ }^{11}$ but clearly an authoritative legal norm provides more than simply a garden-variety reason to act. Consider again George's process of deciding whether to authorize the warrantless electronic surveillance. Suppose he assigns different numerical weights to each of the applicable reasons, on a scale from one (least weighty) to ten (most weighty); he might assign, say, a weight of eight to "the surveillance will promote national security," a weight of five to "the surveillance will invade the privacy of some innocent people," and so on. And suppose that after assigning a numerical weight to each applicable reason, George makes his decision by comparing the total weight of the reasons in favor of the surveillance against the total weight of the reasons opposing it.

Now suppose that in addition to all the other applicable reasons, George considers the fact that the nation's constitution would prohibit the proposed surveillance. Suppose he assigns that reason, too, some numerical weight from one to ten (say, a nine); and suppose that after considering all the applicable reasons together, weighting them and setting them off against the contending reasons, he concludes that the morally best thing to do is to refuse to authorize the surveillance.

This reasoning process seems to miss the point of treating the constitutional provision as an authoritative legal norm; for we do not typically treat legal norms as simply one of many commensurate reasons relevant to action, a reason that can be tossed into the hopper with a host of competing reasons and

${ }^{11}$ For surveys of contemporary debates on these issues, see Shapiro, supra note 6, at 385-93 (generally describing the "paradoxes of authority" - the alleged tension between authority on the one hand and autonomy and rationality on the other); 393 402 (describing and assessing attempts to "weaken" the concept of authority by denying its capacity to impose strict moral obligations); 402-15 (describing and assessing attempts to define the normative mechanics of authoritative obligation). 
that may or may not tip the balance in one direction or the other. Typically we treat legal norms as imposing something akin to a duty to act, albeit a duty that might in some circumstances be vitiated or outweighed by some opposing duty. ${ }^{12}$ Again, the precise strength and nature of this duty need not concern us here; for present purposes we can think of legal authority simply as imposing a prima facie duty to act, one that presumptively outweighs any contrary applicable reasons but that might, on occasion, be outweighed by them.

\section{Noncoerciveness}

The authority of a legal norm also must be noncoercive: The existence and force of the reason to act that it supplies cannot depend on the possibility of formal sanction for violating the norm. It is true that legal norms typically are paired with sanctions to be imposed if they are violated; the threat of punishment for disobedience is a common, perhaps a ubiquitous, feature of legal systems. But legitimate coercion follows legitimate authority, not the other way around.

As a conceptual matter, this is evident in the distinction between an authoritative legal norm and a mere demand backed by a threat. Suppose our chief executive is blackmailed by an opponent of the proposed electronic surveillance who threatens to publicize evidence of George's marital infidelity if he authorizes the program. This threat will of course create a reason, perhaps a very powerful one, for George to act; but it will not be the same sort of reason that the law creates. George will feel no normative compulsion to do the blackmailer's bidding apart from the in terrorem effect of the threat. In considering the constitutional provision, on the other hand, George is likely to feel some compulsion to obey that provision quite apart from

\footnotetext{
12 For an argument that the duty imposed by legal authority cannot be absolute, see Christopher J. Peters, A Matter of Dispute: Morality, Democracy, and LaW 33-36, 44-47 (2011).
} 
any danger of being penalized for not doing so. He is likely, that is, to identify a reason to obey that provision that is entirely independent of the threat of sanction - a reason altogether absent in the case of the blackmailer's threat.

The phenomenon by which a legal subject perceives a reason to obey the law quite apart from the threat of sanction is what H.L.A. Hart famously described as the "internal aspect" of the law. ${ }^{13}$ As a practical matter, the internal aspect is a necessary ingredient of any modern legal system, in which many or most instances of legal disobedience will go undetected and unpunished. Its function is even more vital in the realm of constitutional law, as those subject to constitutional norms often will not be susceptible to "punishment" for "disobedience" in any meaningful sense. Powerful government officials like chief executives, legislators, administrators, and judges often will be able to violate constitutional norms without detection, by, for example, concealing constitutional violations or dressing them up to look constitutionally permissible (in a cleverly drafted judicial opinion, for instance). And of course the ultimate legal subject in the constitutional context is the democratic majority itself, an entity that cannot be formally "punished" for choosing to exceed its supposed constitutional limitations.

This, again, is not to deny that punishment often (justifiably) follows disobedience of legal norms. Legal subjects, after all, sometimes will disobey the law in bad faith, or will mistakenly believe they are justified in disobeying the law; punishment might be appropriate to retribute for or deter these instances. ${ }^{14}$ The point is only that the existence of legal authority cannot itself depend on the threat of formal punishment for disobedience.

\footnotetext{
13 See H.L.A. Hart, The Concept of Law 56-57 (2d ed. 1994) (1961).

14 Punishment might even be justified in instances where a legal subject has jus tifiably disobeyed the law. See Larry Alexander \& Emily Sherwin, The Rule of Rules: Morality, Rules, \& THE Dilemmas of LAW 53-95 (2001); but see Heidi M. Hurd, Justifiably Punishing the Justified, 90 MicH. L. REv. 2203 (1992).
} 


\section{Source-dependence}

The authoritativeness of a legal norm also depends on the source of that norm; the norm supplies a special reason to act (one that is operative, has special normative force, and does not turn on coercion) only if that norm derives from a certain type of person, institution, or process. Imagine a prohibition on unreasonable searches that has exactly the same substantive content as the prohibition contained in the constitution applicable to our hypothetical chief executive; but suppose that prohibition is contained in the constitution of a neighboring country, or in a defunct version of her own nation's constitution, or on a cocktail napkin with the word "Constitution" scrawled on it. None of these supposed norms will have the same impact on George's reasoning as will a norm actually embedded in his nation's constitutional law. He is unlikely to understand these pseudo-legal norms as creating an actual operative reason for him to act - certainly not an operative reason that has the kind of special normative force that law possesses, akin to a prima facie duty. The obvious problem is that these supposed norms do not derive from a process George recognizes as a legitimate source of law-creation within the system to which he is subject.

Note that the problem is not (necessarily) that these norms lack the status of law: The foreign constitutional provision is law, albeit in another system, and the defunct provision was law in the system in question. (We might even imagine a bizarre secret society that treats scribblings on cocktail napkins as legally binding.) The problem, rather, is that these supposed norms are not legally authoritative in the context at hand; and that is a function of their source.

\section{E. Salience}

Finally, in order for a legal norm to be effectively authoritative, not just theoretically so, it must provide a reason to act whose possession of these other criteria - its operativeness, 
special force, noncoerciveness, and source-dependence - is sufficiently salient, that is, evident or accessible to a reasonable legal subject.15 The requirement of salience flows from the fact that any given legal subject can perceive legal authority, like other factors relevant to her moral reasoning, only through her own capacity to engage in such reasoning. Legal authority that exists in some objective sense but is not capable of being perceived by a legal subject is useless in practice.

Suppose, for instance, that at some time in the distant past, the legislature in our fictional democracy, following all the required procedures, had enacted a statute forbidding precisely the type of surveillance George is now considering; but suppose that due to some clerical error, the legislation was not properly recorded in the country's official statute books and is unknown to George and his advisors. Imagine that one of these advisors now unearths the text of this ancient statute, but can find no evidence that the text was ever validly enacted into law. The statutory prohibition seems to meet the other requirements of authoritative law: It creates an operative reason for action, one with special normative force that does not turn on coercion and that is dependent on the source of the relevant norm. But as a practical matter George is unlikely to recognize that the statute creates this kind of legal reason, because at least one of these qualities - the statute's source - is not apparent to him, and thus its other qualities are concealed as well.

Here again it is easy to miss the true nature of the problem. The problem is not (necessarily) that George fails to recognize that the statute provides some sort of reason relevant to his de-

\footnotetext{
15 Salience might be seen as an aspect, or perhaps an implication, of the requirement of "promulgation" that Lon Fuller cited as one of the necessary elements of effective law. Fuller argued that law can only function as law if legal officials "publicize, or at least ... make available to the affected party, the rules he is expected to observe.” LON L. FUller, The Morality OF LAW 39 (rev. ed. 1969); see also $i d$. at 49-51. This requirement seems to entail a concomitant requirement that the rules' status as binding law be understandable by the affected party - i.e., a requirement of what I have called salience.
} 
cision how to act. He may take the statute as a sort of advice or advocacy, for example; or perhaps he has a strange fetish for statute-like communiqués and is inclined to treat it as creating an actual operative reason for action. The problem, rather, is that whatever reason to act, or to think about how to act, George attributes to the statute, it is unlikely to be the same sort of reason he would attribute to the statute were he aware of its status as valid law. What causes the statute to lack effective authority is not the legal subject's failure to take any account of it in his reasoning, but rather his failure to take proper account of it as an authoritative norm.

This point about salience may seem so obvious as to be trivial: Of course the reasons supplied by authoritative law, like any morally applicable reasons, must actually be accessible by the person doing the reasoning in order to be effective; but so what? Why should we consider this quality to be a central property of legal authority? As it happens, standard accounts of legal authority attribute substantial importance to the property I am referring to here as salience (although typically they do so sub rosa). Standard accounts typically hold that authoritative norms must be "content-independent," a term coined by H.L.A. Hart. ${ }^{16}$ Hart described the concept of contentindependence this way:

Content-independence of commands lies in the fact that a commander may issue many different commands to the same or to different people and the actions commanded may have nothing in common, yet in the case of all of them the commander intends his expressions of intention to be taken as a reason for doing them. It is therefore intended to function as a reason independently of the nature or character of the actions to be done. ${ }^{17}$

\footnotetext{
16 Hart first used the term in H.L.A. HART, Legal and Moral Obligation, in Essays IN MORAL PhILOSOPHY 102 (A.I. Melden, ed. 1958).

17 H.L.A. HART, Commands and Authoritative Legal Reasons, in EsSAYS ON BENTHAM 254-55 (1982).
} 
Post-Hartian theorists of legal positivism almost universally have endorsed the notion that authoritative law must supply "content-independent" reasons in this sense. ${ }^{18}$ But the precise concept of content-independence is mysterious and contested. 19

I believe the idea of content-independence is best seen as shorthand for the conjunction of three of the properties of legal authority I have canvassed here, namely operativeness, sourcedependence, and salience. The central thrust of contentindependence is the capacity of an authoritative norm to motivate a legal subject to take some action she would not otherwise have taken, precisely because it is an authority that commands the action. Part of this work is done by the property I have termed operativeness: An operative reason is one that actually changes the existing balance of applicable reasons and thus is capable of motivating the actor to do something she would not have done without that reason. Another part of the work is done by the property of source-dependence: The special reason provided by an authoritative legal is special precisely because it is the law (or some other authority) that creates the norm. And the final bit of the work is done by the property of salience: Authority requires that actors subject to it recognize the special nature of the reason it supplies in order for a norm "to be taken as a reason" for doing what it commands. These three properties, taken together, seem to capture what Hart meant by content-independence: the capacity of an authoritative command to create its own "reason for doing" a thing, a reason that is "taken as" a reason and that is "independent[] of the nature or character of the action] to be done" - that is, of

\footnotetext{
18 See sources cited in Sciaraffa, supra note 9; see also Shapiro, supra note 11, at 389-91.

19 See Sciaraffa, supra note 9; P. Marwick, Law and Content-Independent Reasons, 20 OXFORD J. LEG. STUD. 579-96 (2000).
} 
the existing (prelegal) balance of applicable reasons, as perceived by the actor. ${ }^{20}$

$* * *$

In order for a rule, command, or other norm to possess effective legal authority, then, it must possess at least the five characteristics I have described in this section. It must be operative - capable of altering the balance of applicable reasons for action. It must have special normative force, akin to a prima facie duty to act. It must be noncoercive, deriving its operativeness and special force from something other than the threat of sanction for disobedience. It must be source-dependent - reliant for its other qualities on the identity of the process that

\footnotetext{
${ }^{20}$ Hart does use the locution of "intent" to describe content-independent reasons ("[T] he commander intends his expressions of intention to be taken as a reason for doing [what he commands]"), an ingredient that Stefan Sciaraffa sees as essential to the concept of content-independence and thus to the concept of legal authority more generally. See Sciaraffa, supra note 9. I doubt, however, that anything that can properly be called "intent" plays a necessary role in legal authority. It is true that often there will be some actor (individual or collective) clothed with legal authority that can be said to have "intended" that its commands be followed, but legal authority can and often does exist without this phenomenon. There are, first of all, wellknown conceptual difficulties with attempts to ascribe "intent" to collective decisionmaking bodies such as legislatures. See, e.g.., RonALD DwORKIN, The Forum of Principle, in A MATTER OF PRINCIPLE 33, 34-57 (1985) [hereinafter DwORKIN, Forum of Principle]. Even if we assume a lawmaker that is capable of forming an intent, it is likely that its laws will apply in some circumstances that they did not foresee and with respect to which they could not therefore have formed any intent; this is the import of the legal "principles" describe by Ronald Dworkin, for example. See Ronald Dworkin, The Model of Rules I, in TAKInG Rights SERIOUsly 14-45 (19771978). And it is likely that legal norms can arise without any actor's ever consciously forming an intent that they be legal norms, as in cases of law by custom.

I think the function that Hart (implicitly, perhaps accidentally) and Sciaraffa (deliberately) ascribe to intent within the concept of authority can be served just as well by the property of source-dependence combined with the property of salience. What is crucial in Hart's description of content-independence is not the fact that the commander intends his commands to be taken as reasons for action, but rather the fact that those subject to his commands perceive those commands as reasons for action. The quintessential quality of authoritative commands to which Hart alludes that they be taken as reasons (or as providing reasons) for action without regard to what it is they command - can be explained as readily, perhaps more readily, by their property of source-dependence than by the (contingent) possibility that some actor intends for them to be taken this way.
} 
generated it. And it must be salient; its possession of these other characteristics must be sufficiently evident or accessible to a reasonable legal subject.

\section{F. A Note on the Identity of the Legal Subject in Debates about Constitutional Rights}

General accounts of legal authority - that is, attempts to justify the authority of most or all legal norms within a system of law - must explain how law can impose a prima facie duty of obedience on a wide range of legal subjects in a wide range of circumstances, from chief executives deciding how to treat suspected terrorists to pedestrians deciding when to cross the street. Such an account would have to explain why people or organizations acting in a private capacity - as subjects rather than makers or enforcers of the law - have a duty to obey what H.L.A. Hart called "primary" legal rules, that is, rules by which "human beings are required to do or abstain from certain actions." ${ }^{21}$ It also would have to explain why people acting as legal officials - chief executives, legislators, judges, bureaucrats, on down to citizens exercising their rights to vote and to engage in political speech and association - have a duty to obey the "secondary" rules ${ }^{22}$ that determine their powers and responsibilities as legal officials, rules that establish the legal system of which they are a part and govern how that system is to function. ${ }^{23}$

The inquiry for purposes of this article need not be nearly so broad. In most instances, constitutional rights purport to directly constrain only what in American doctrine are called "state actors" - government officials and institutions. ${ }^{24}$ While

\footnotetext{
${ }^{21}$ HART, supra note 13 , at 81.

22 See id. (defining "secondary" legal rules).

23 I have attempted to sketch the foundations of this sort of general account in PETERS, supra note 12.

24 The Thirteenth Amendment to the U.S Constitution is an exception to this general rule, prohibiting as it does "slavery or involuntary servitude" regardless of
} 
we often think of the Constitution as consisting of Hartian secondary rules, in fact constitutional rights typically act as primary rules with respect to these actors. Theorists, politicians, and others often speak - question-beggingly, I think - of constitutional rights as constraints "on the majority," 25 as if government officials somehow could and do perfectly channel something we can call majority will. But of course political majorities are collections of individuals, each of whom becomes a part of that majority only by acting (typically by voting) based on her own process of reasoning about how to act; the mythical "will of the majority" really is the product of a collection of individual wills. ${ }^{26}$ So it will never be the case that some entity called "the democratic majority" will engage in a collective process of self-conscious reasoning about whether to obey a constitutional right or other norm. Nor is it clear that those charged with "representing" the majority always should mechanically implement its will, even if that will can accurately be identified. ${ }^{27}$ And, as Ely and Footnote Four remind us, it is far from inevitable that government officials always will discharge their duties, whatever those may be, in complete good

its source. See U.S. Const. Amend. XIII. The Eighteenth Amendment (establishing Prohibition) was another exception before it was repealed by the Twenty-First. See U.S. Const. Amend. XVIII, XXI.

25 See, e.g., Alexander M. Bickel, The Least Dangerous Branch: The Supreme Court AT THE BAR OF Politics 16-23 (2d ed. 1986) (coining the term "countermajoritarian difficulty" to describe questions about the democratic legitimacy of judicial review); but see RONALD DWORKIN, Introduction: The Moral Reading and the Majoritarian Premise, in Freedom's Law: The Moral REAding of THE American CONSTITUTION 1, 15-20 (1996) (questioning the equation of democracy with majoritarianism); EISGRUBER, supra note 4, at 49-52 (questioning the assumption that majoritarian political institutions always best "speak for the people").

26 For an argument that majorities should not be treated as monolithic entities in constitutional theory, see Christopher J. Peters, Persuasion: A Model of Majoritarianism as Adjudication, 96 Nw. U. L. REV. 1, 22-25 (2001). For a valuable and nuanced discussion of the centrality of disagreement to democratic legislation and some implications for legal theory, see WALDRON, supra note 4, at 21-146.

27 On the various ways in which government officials might be thought to represent democratic majorities, see Hanna Fenichel Pitken, The Concept of REPRESENTATION (1967). 
faith, and far from certain that in a democracy the bare majority will always should prevail. ${ }^{28}$

For most purposes, then, the relevant legal subject with respect to constitutional rights will be a government official (like George) or government institution (like a legislature). Their dilemma will be whether to obey what a constitutional right commands in cases where that command conflicts with their own best judgment about what to do. In some instances the relevant legal subject will be a citizen - deciding, for example, whether to vote for a chief executive or legislator who (in the citizen's judgment) did or did not violate some constitutional right. And often the relevant legal subject will be a judge who must decide whether and how to interpret and enforce constitutional rights. Things stand a bit differently for the judge: Typically (though not always) the question for her will be, not whether she herself is directly constrained by constitutional rights, but whether she should hold that some other government actor is so constrained. ${ }^{29}$ For the judge, then, the question of the authority of constitutional rights usually is filtered through the question whether she ought to obey other rules (secondary rules in the Hartian sense) that direct her to enforce those rights. ${ }^{30}$ This is still a question of legal authority just legal authority that is once-removed.

\footnotetext{
28 See my description of the Ely/Footnote Four approach in Part IV.A, infra.

29 There are of course potential and actual exceptions: Constitutional rights may purport to directly constrain, not just the democratic majority, but also the conduct of judges and other aspects of the judicial process. Many provisions of the American Bill of Rights fit this description. See, e.g., U.S. CONST. AMEND. V (requiring grandjury indictment and due process of law and prohibiting double jeopardy and compelled self-incrimination); AMEND. VI (regulating aspects of criminal prosecutions); AMEND. VII (guaranteeing trial by jury in certain civil cases); AMEND. VIII (prohibiting cruel and unusual punishments and excessive bail).

30 Some of these secondary rules will be constitutional in stature. E.g., U.S. Const. ART VI, cl. 2 ("This Constitution, and the Laws of the United States which shall be made in Pursuance thereof, ... shall be the supreme Law of the Land; and the Judges in every State shall be bound thereby ...."). Others will take the form of statutes, sub-statutory regulations, or common-law rules: codes governing the
} 
Which brings us back to the central premise of this paper: Any plausible defense of constitutional rights must address the question of their legal authority. Institutional designers have no good reason to adopt constitutional rights that lack authority; legal subjects have no (or at least very little) good reason to obey constitutional rights that lack authority. ${ }^{31}$ Given all of this, it is not clear why one would endorse any normative justification of constitutional rights that fails to explain their authority as law.

\section{Substantive JUSTIFICATIONS AS ACCOUNTS OF LEGAL}

\section{AUTHORITY}

How then do the alternative defenses of constitutional rights I mentioned in the Introduction fare as accounts of legal authority? Some better than others, as it turns out. In this Part, I explore the implicit narratives of legal authority embedded within Substantive justifications and find them wanting. Just how unsatisfactory the narrative is, however, depends on which version of a Substantive justification is in play. I have been able to identify two principal variants, which I call the Simple and the Nuanced versions, and the latter holds up as an account of legal authority somewhat better than the former.

\section{A. Substantive Justifications: The Simple Version}

What I will call the Simple Substantive Justification of constitutional rights holds as follows: Constitutional rights are

structure of the judiciary and the judicial process, rules of procedure, court rules, precedential decisions, norms of professional conduct, and the like.

31 If a legal subject will be sanctioned in some way for disobeying a constitutional right, she may have a good reason to obey it even if it lacks (or if she thinks it lacks) authority. As I suggested in Part II.A.3, however, sanctions must follow authority, not the other way around; and so, while it is conceivable that sanctions sometimes might justifiably follow from disobedience even to legal norms that lack authority (see infra note 14), it is doubtful that such instances will be frequent in a legitimate legal system. Subjects of such a system thus will only infrequently have a coercionbased reason to obey nonauthoritative legal norms. 
normatively justified as means of promoting particular states of affairs thought to be morally desirable. The quotation from the ACLU website that opens this paper suggests a Simple Substantive Justification. That quotation identifies "free speech" as a category of "rights" to which people are "entitled" "as human beings," rights that "naturally" belong to us. ${ }^{32}$ Protection of "free speech," in other words, is thought to be a morally desirable state of affairs. And on this view, constitutional rights - those embodied in "the First Amendment" and in the "entire Bill of Rights" of which it is a part - were "created" as ways "to protect" free speech and these other natural rights, that is, to promote the morally desirable states of affairs that arise when free speech and other natural rights are protected.

For our purposes, a Simple Substantive Justification like this one has two important features. First, it is substantive in the sense that it is concerned ultimately with the moral status of results or outcomes - with the states of affairs likely to result from enforcement of and obedience to constitutional rights, and with whether those states of affairs are morally desirable. (It is not "procedural," in that its ultimate concern is not with the process by which these states of affairs are achieved. ${ }^{33}$ ) Second, it is specific in that its substantive focus is quite narrow, trained on certain identified outcomes - on "protecting free speech," say, or (a bit more broadly) on "protecting natural rights," rather than on serving the goals of "morality" or "acting morally" as a general matter. The former component will prove troublesome for substantive justifications generally, but it is the latter component - specificity - that is most problematic for the Simple Substantive Justification.

\footnotetext{
32 To be precise, the quotation attributes this sort of natural-law view to "this country's original citizens" as framers and adopters of the Bill of Rights. But I think it is safe to read the quotation as endorsing this understanding.

33 On this point, see also the discussion supra notes 63-64 and accompanying
} text. 
Before assessing the Simple Substantive Justification against the aspects of legal authority identified in the previous Part, I should mention that despite the popularity of that justification in political and public rhetoric, examples of it are difficult to find within academic theory. ${ }^{34}$ I think there is good reason for this, as my discussion should reveal. But I don't think the scarcity of serious instances of the Simple Substantive Justification renders it a mere straw man. So long as that justification holds sway over much of the public's thinking about constitutional rights, as my opening quotes suggest it does, there is value in probing it for weakness.

1. Operativeness (and Special Force, Noncoerciveness, and Salience). - Weakness number one turns out to be the failure of the Simple Substantive Justification to account for perhaps the most essential feature of legal authority: its operativeness. Operativeness, remember, is the requirement that an authoritative legal norm provide a reason for a legal subject to act, not just to believe something or to think about how to act. And on the Simple Substantive Justification, constitutional rights fail to do this.

Consider again the hypothetical case of the chief executive, George, deciding whether to authorize warrantless electronic

\footnotetext{
34 A possible exception is Randy Barnett's defense of the authority of the American Constitution. Barnett contends that the Constitution is binding (that is, that it possesses authority) because it tends to protect a particular understanding of "natural" rights, namely the libertarian conception that Barnett himself holds and claims to share with many of the Framers. See RANDY E. BARnETT, RESTORING THE Lost CONSTITUTION: THE PRESUMPTION OF LIBERTY 53-86 (2004) (endorsing this understanding of "natural" rights and attributing it to the "founding generation"); see also $i d$. at 89-115 (espousing an originalist interpretive methodology as the best way to implement these rights). Barnett, typically an astute theorist, is one of the few participants in the normative debate about constitutional rights and judicial review to directly engage the question of legal authority (which he refers to as the question of "legitimacy," see, e.g., id. at 48); this makes it all the more disappointing that Barnett seems to endorse the Simple Substantive Justification. I should note that Barnett's defense of constitutional rights generally - not just the specific set of constitutional rights embodied in the U.S. Constitution - appears to track what I call below the Nuanced Substantive Justification. See infra note 37.
} 
surveillance of terrorism suspects. Suppose that nonlegal reasons (that is, reasons other than those provided by law) $A, B$, and $C$ favor authorizing the surveillance, while nonlegal reasons $D, E$, and $F$ oppose authorizing it. A correct assessment of the balance of applicable nonlegal reasons will require either a decision authorizing the surveillance (call it $O S$, with the $O$ standing for "outcome" and the subscript $S$ standing for "surveillance") or a decision failing to authorize the surveillance $\left(O_{(-S)) .}{ }^{35}\right.$ Now suppose constitutional right $R$ forbids authorizing the surveillance. What effect can $R$ have on the balance of moral reasons relevant to George's decision?

On the Simple Substantive Justification it can have no effect at all. That justification offers the following reason to obey constitutional rights: Doing so will promote a particular morally desirable state of affairs. But surely a legal subject like George already has sufficient reason to act in a way that promotes a morally desirable state of affairs, quite apart from the law. If a correct assessment of the balance of applicable nonlegal reasons requires George to choose $O_{(-S)}$, the fact that $R$ also requires $O_{(-S)}$ changes nothing; the requirements of $R$ are entirely redundant of the existing requirements of (nonlegal) morality.

By the same token, if the only reason to act provided by $R$ is to promote a morally desirable state of affairs, then $R$ provides no reason to act in a way that would not do that. So, if a correct assessment of the balance of applicable nonlegal reasons requires George to choose $O_{S}$, the fact that $R$ requires him to choose $O_{(-S)}$ cannot provide a morally valid reason to act.

On the Simple Substantive Justification, then, constitutional rights supply no reason to act either consistently or inconsistently with the requirements of nonlegal morality. As Scott

\footnotetext{
35 For simplicity's sake I put aside the arguable possibility that a correct assessment of the balance of reasons will permit but not require either action. This possibility does not materially affect the analysis.
} 
Shapiro puts the point, "when [legal] authorities are wrong, they cannot have the power to obligate others - when they are right, their power to obligate is meaningless. ... [T] he institution of [legal] authority is either pernicious or otiose." ${ }_{36}$ The existence of the constitutional right adds nothing at all to the existing moral calculus; it fails to supply an operative reason for action.

And note that this failure of operativeness implies also a failure of several other of the necessary elements of legal authority canvassed in the previous section. A nonoperative reason (that is, a reason that does not exist, at least not as a reason to act) cannot be a reason that has special normative force, akin to a prima facie duty. Nor can it be a reason whose (nonexistent) operativeness and special force is salient to a reasonable person ostensibly subject to legal authority.

This last point, though obvious in the abstract, deserves a bit of elucidation, because it is the lack of salience on the Simple Substantive Justification that dooms it "on the ground," so to speak. The teeth of constitutional rights - their practical value - is of course their capacity to motivate legal officials, citizens, and other relevant actors to do things they otherwise would not do; no one cares about constitutional rights or the authority they possess when those rights only require what the relevant actors would do anyway. Constitutional rights must be capable of causing a decisionmaker like George to act in some way - to decline to authorize warrantless surveillance of terrorism suspects, for instance - that he would not have acted absent those rights. And the practical problem with the Simple Substantive Justification is that it does not allow constitutional rights to do this.

Suppose George concludes, based on his assessment of the applicable nonlegal reasons, that the morally best state of af-

\footnotetext{
36 Shapiro, supra note 6, at 383.
} 
fairs includes authorization of the warrantless surveillance. The Simple Substantive Justification says to George, in essence, "You must honor the right against unreasonable searches $(R)$ because doing so will promote a morally desirable state of affairs"; but this is precisely the assertion with which George disagrees: George believes the morally desirable state of affairs in that case includes authorization of the surveillance, not refusal to authorize it as $R$ requires. As a practical matter, the justification can offer George no reason to do something other than what he has already concluded is morally right.

This would be true, moreover, even if George were wrong about the morally desirably state of affairs in his case. George's (erroneous) assessment that the morally desirable state of affairs includes authorization of the surveillance will blind him to the existence of a reason to obey $R$ (namely that doing so will promote a morally desirable state of affairs). $R$ 's actually authority, that is, will lack salience with respect to George. And this means that the Simple Substantive Justification is dead in the water, not just as a justificatory theory about the authority of constitutional rights, but also as a practical prescription for why constitutional rights matter and deserve obedience in the world.

2. Source-dependence. - Weakness number two of the Simple Substantive Justification is its inability to clothe constitutional rights with source-dependence. A source-dependent norm, remember, is one whose authority (to be precise, its combination of operativeness, special force, and noncoerciveness) derives from its pedigree - from its origin in some special person, institution, or process. If the authority of a norm is source-dependent, the same norm would not possess authority (at least not the same degree of authority) if it had come from some other source. A constitutional right generated by a nation's legally sanctioned procedures for creating constitutional 
law possesses authority that the exact same "constitutional right" lacks when it is scribbled by a bar patron on a cocktail napkin.

Constitutional rights lack source-dependence on the Simple Substantive Justification, because any reason to obey them does not depend at all on their source. If George's obedience to $R$ is more likely than his disobedience to promote a morally desirable state of affairs, then this is true regardless of whether $R$ was ratified by his nation's pedigreed constitution-making process or merely scribbled on a napkin. George's reason to obey $R$ has nothing to do with the process that generated $R$ and everything to do with the outcome of obeying $R$. Even if $R$ happens to have some moral authority over George - even, that is, if George has some operative reason to obey $R-R$ lacks legal authority over him. Its normativity, if it exists, resides in what $R$ is telling George to do or not to do, not in where $R$ comes from.

\section{B. Substantive Justifications: The Nuanced Version}

So the Simple Substantive Justification falls flat as an account either of the operativeness or of the source-dependence of constitutional rights - and thus of their legal authority tout court. What I will call the Nuanced Substantive Justification is a considerable improvement over the Simple version (though ultimately not improvement enough, I will contend). The Nuanced Substantive Justification holds as follows: Constitutional rights are justified as means of promoting morally desirable states of affairs, whatever they turn out to be. The quotation from FreedomWorks above might be read to suggest a Nuanced Substantive Justification (although it also can be read as a Simple version). The "purpose" of the Constitution, according to the quote, is "to protect the natural rights of citizens ... from ... the overreaching hand of government," among other dangers. The quotation does not specify any particular 
"natural rights" deserving of protection (although we might think of the very concept of "natural rights" as a specification of the content of morality - this is the sense in which the quotation might be read as a Simple account). Read this way, the quotation thus suggests that constitutionally enshrined rights are designed to promote some relatively broad spectrum of morally desirable states of affairs, perhaps even a spectrum that is indeterminate and thus incapable of being specified into particulars. ${ }^{37}$

Like the Simple version, the Nuanced Substantive Justification is substantive in its ultimate concern with the moral status of outcomes, rather than with the status of the procedures used to reach outcomes. Unlike the Simple version, however, the Nuanced version does not specify any particular state or states of affairs that are morally desirable and thus constitute the objectives of constitutional rights. The idea is that enforcing and obeying constitutional rights is more likely to get us to some morally desirable place - even if we don't now know, or can't now agree, where that place is - than is failing to enforce and obey them.

This lack of outcome-specificity in the Nuanced Substantive Justification means the normative mechanics of the account work in a crucially different way than on the Simple version.

\footnotetext{
37 I noted above (see supra note 34 ) that while Randy Barnett's specific justification of the American constitution appears to be a Simple Substantive account, his general justificatory theory of constitutional law might be understood as a Nuanced Substantive account. Barnett argues that constitutional law possesses "legitimacy" - by which he means it "merits the benefit of the doubt and a prima facie duty of obedience," a concept akin to what I call "authority" - if and only if the processes that generate and enforce that law "provid[e] adequate assurances that the laws [those processes] validat[e] are just." BARNETT, supra note 34, at 48. This approach appears to attribute authority to constitutional law insofar as obedience to its commands is - not likely to promote some particular morally desirable outcome - but likely to promote whichever outcome turns out to be morally desirable. That would be an example of the Nuanced Substantive Justification that I describe in this section. As Barnett notes, "[o]ne can accept the [general] ... conception of legitimacy advanced [in his work] without concurring on a particular theory of justice." Id. at 47.
} 
The normative bite of the Simple version was its promise to promote particular states of affairs; if one thinks a given state of affairs is normatively desirable, then for that reason one ought to enforce or obey a constitutional right that will promote that given state of affairs. The superficial attraction of this quasi-logic is evident in the ACLU quotation: Of course free speech is a good thing! Of course natural rights are morally desirable! Who could question constitutional rights that would produce such obviously good results?

It is precisely this illogic, as we've seen, that dooms the Simple Substantive Justification as an account of legal authority. But the logic of the Nuanced version is different - less intuitively appealing, perhaps, but ultimately more resilient. The idea here is that even if we don't know for sure which of a number of possible states of affairs would be most morally desirable - or if we disagree with each other on that question enforcing and obeying constitutional rights will lead us to the right answer, whichever it may be. As Jeremy Waldron (himself no defender of constitutional rights) puts it, constitutional rights will help us "get at the truth ..., whatever the truth turns out to be." ${ }_{38}$ The normative bite of the account is its promise, not to promote a particular result or outcome, but to promote whichever result or outcome happens to be morally best.

Even from this bare-bones description, we can begin to see how the Nuanced Substantive Justification might avoid the rocky shoals of legal authority that wrecked its Simple cousin. On the Simple version, a constitutional right adds nothing to the existing duty of a legal subject to pursue a morally desirable state of affairs. But on the Nuanced account it might add something important. If the legal subject doesn't know which state of affairs is morally desirable, or can't agree with other decisionmakers on that question, she nonetheless can obey the

\footnotetext{
38 Waldron, Core Case, supra note 4, at 1373 (emphasis added).
} 
constitutional right with the assurance that it will lead her to that result, whatever it may be. The supposed capacity of constitutional rights to overcome moral disagreement or uncertainty might supply the operative reason to act that the Nuanced account is missing. The salience, moreover, that is absent from the Simple account seems to emerge on the Nuanced version. If the legal subject wrongly thinks the result of obeying constitutional right $R$ would be morally undesirable, she might do it anyway - on the ground that she might be wrong, and $R$ might be correct, about the morally desirable outcome.

As this point about salience suggests, on the Nuanced Substantive Justification the operativeness of constitutional rights might be (in fact must be) source-dependent as well. The Nuanced version holds that obedience to a constitutional right $R$ is more likely than is disobedience to promote morally desirable outcomes. If this is so, it can only be a function of some comparative advantage in moral decisionmaking possessed by whatever process generated $R$ vis-à-vis the legal subject's own reasoning. If no such advantage existed - if $R$ were not a morereliable indicator of moral desirability than the subject's own judgment - there would be no point in obeying $R$; the legal subject should obey her own unalloyed judgment instead. The subject's reason to obey $R$, then, turns on something about the process that generated $R$ : It turns on $R$ 's source.

1. The idea of a comparative decisional advantage. - I want to expand a bit on this subject of source-dependence, and particularly on the necessity that the Nuanced Substantive Justification persuasively back up the source-dependence it offers. It is the essence of source-dependence that the subject have some good reason or set of reasons to defer to the person or institution or procedure that generated a norm. Here perhaps the paradigmatic example is a patient's deference to the "orders" of her doctor because of the doctor's vastly greater know- 
ledge of medical matters. As this example suggests, any account of authority must supply some persuasive reason or set of reasons for this kind of deference. In a sense, the existence of such reasons is the essence of authority; and the right kinds of reasons turn out to be very difficult to come by. ${ }^{39}$

The reason given by the Nuanced Substantive Justification is this: The process $P$ that generated constitutional right $R$ is more likely to produce good decisions about morally desirable states of affairs than is the judgment of the legal subject absent $R$. (Remember here that by "legal subject" we mean a government official or citizen acting by virtue of the democratic political process, or, sometimes, a judge deciding whether and how to constrain that process.) Any given example of a Nuanced Substantive Justification will have to provide a convincing narrative of why this reason exists, why it is operative and strong enough to constitute a prima facie duty, and thus why the condition of source-dependence is met.

In a moment I will describe perhaps the best-known variety of Nuanced Substantive Justification (the Hamiltonian approach) and explain the account of comparative decisional advantage it offers. But first I should note that my goal in this paper is not to assess the persuasiveness of that or any other particular theory of comparative decisional advantage. More broadly, my goal is not to assess Substantive justifications (or for that matter Procedural ones) on their merits. (That project has for a long time been the central preoccupation of academic debates about constitutional rights. ${ }^{40} \mathrm{My}$ goal, rather, is to evaluate whether any example of these respective types of justification (whatever its apparent attractiveness on the merits) is capable of providing a coherent account of legal authority.

\footnotetext{
39 For a couple critical surveys of various categories of reasons that have been offered to justify legal authority, see Shapiro, supra note 6; PETERS, supra note 12, at 39-66.

40 See, for example, the sources cited supra note 4.
} 
So I will argue below that Nuanced Substantive Justifications stumble badly as accounts of legal authority precisely because they are centered on the notion of comparative decisional advantage - quite regardless of whether any particular story about comparative decisional advantage seems compelling.

2. The classic Hamiltonian account as a type of Nuanced Substantive Justification. - A Nuanced Substantive Justification thus must explain why the procedures that generate constitutional rights are comparatively better at moral decisionmaking, at least about certain matters, than are the subjects of constitutional rights - government officials, citizens, and (secondarily) judges. In a system like the American one, any such account will have two focal points: the process of creating general constitutional norms (constitutional framing) and the process of applying those general norms in specific circumstances (constitutional adjudication). ${ }^{41}$

In Federalist No. 78, Alexander Hamilton sketched a classic defense along these lines, outlining themes that continue to resonate in contemporary accounts. For Hamilton, the framing of a constitution was a direct expression of "the power of the people," 42 asserted not in the ordinary democratic way through "the major voice of the community" 43 - but rather by the sort of "solemn and authoritative act" that is capable of "annull[ing] or chang[ing] the established form" of government. ${ }^{44}$ Through the lens of the Nuanced Substantive Justifi-

41 This dichotomy is a simplification for purposes of illustration. It is implausible that there would be a hermetic separation between the creation and the application of constitutional norms; in any system featuring common-law elements, the application of general norms will itself modify those norms or create new ones. Nor is formal adjudication likely to be the only context in which constitutional norms are applied; legislators, other government officials, and voters can be said to "apply" constitutional norms whenever they allow their decisionmaking to be guided by them.

42 Federalist No. 78, in The Federalist Papers 436, 439 (Isaac Kramnick ed., 1987) (Alexander Hamilton).

43 Id. at 441.

${ }^{44} \mathrm{Id}$. at 440. 
cation, the suggestion here - one that also animates contemporary theorist Bruce Ackerman's influential account of "constitutional moments" at which "higher lawmaking" occurs 45 - is that there is something special (specially participatory, specially inclusive, specially deliberative) about the process of constitution-framing that gives it a comparative decisionmaking advantage over the ordinary democratic process, at least with respect to certain types of decisions.

Hamilton supplemented his account of the Framing with a description of constitutional adjudication in which "independent" judges, protected by lifetime tenure, ${ }^{46}$ would act as "bulwarks of a limited Constitution," not only to prevent purely "legislative encroachments" on constitutional limitations, but also "to guard ... the rights of individuals from the effects of those ill humors, which the arts of designing men, or the influence of particular conjunctures, sometimes disseminate among the people themselves." ${ }_{47}$ This is an early statement of a familiar idea within American constitutional theory: that the relative political insularity of judges enables them to resist the push-and-pull of everyday democratic politics and thus to better promote those states of affairs that everyday politics tends to disregard or compromise (individual and minority "rights," for example, or enduring "values" or fundamental "principles"). Hamilton thus begat a tradition later taken up by Alexander Bickel, who suggested that "the leisure, the training, and the insulation" of judges gives them "certain capacities for dealing with matters of principle that legislatures and executives do

45 See generally 1 Bruce Ackerman, We the People: Foundations (1991) [hereinafter Ackerman, Foundations]; 2 Bruce Ackerman, We the People: TRANSFORMATIONS (1998). Ackerman describes in detail the process of higher lawmaking in ACKERMAN, FOUNDATIONS, supra, at 266-94 (chapter 10).

46 See Federalist No. 78, supra note 42, at 436-38 (describing the connection between lifetime tenure and judicial independence).

${ }^{47} \mathrm{Id}$. at 440 . 
not possess," ${ }^{48}$ and by neo-Bickelians like Christopher Eisgruber and Lawrence Sager, who point to judicial "disinterestedness" (Eisgruber) or "detach[ment]" (Sager) as comparative advantages over democratic politics in "resolv[ing] issues of principle" (Eisgruber) or achieving "conformity with fundamental requirements of political justice" (Sager).49

As I will discuss in Part IV, the Hamiltonian account and its recent variants need not be understood as examples of the Nuanced Substantive Justification; they might be seen as types of Procedural Justification instead.50 But note that if we do understand them in Nuanced Substantive terms, these accounts seem to avoid the glaring shortcomings of their Simple Substantive cousins. Hamilton and his heirs defend judicially enforced constitutional rights, not as devices to generate specified (and thus controversial) states of affairs, but rather as processes for reaching morally desirable states of affairs, whatever those states of affairs turn out to be. Thus they appear to offer a reason for obeying constitutional rights that is operative, in that it constitutes a new reason to act; sourcedependent, in that its authority depends on the process that generated the rights; and salient, in that one might (wrongly) disagree with the substance of a constitutional right and still have reason to obey it. That reason is the likelihood that any disagreement with the substance of the right is mistaken that the procedures for creating, interpreting, and enforcing constitutional rights are comparatively better moral decisionmakers than the unalloyed judgment of the particular citizen, judge, or government official.

\footnotetext{
48 BiCKEL, supra note 25 , at 25.

49 See generally EISGRUBER, supra note 4 (quoted text at 57-59); SAGER, supra note 4 (quoted text at 74,19 ).

50 See infra Part IV.B.
} 


\section{A More-nuanced Look at the Nuanced Version}

In fact, however, the Nuanced Substantive Justification offers a less-persuasive account of legal authority than at first it seems. That justification requires, unavoidably, that legal subjects, in assessing the authority of a constitutional right on any given occasion, bring to bear their own moral judgments about desirable states of affairs. Doing so inevitably compromises the salience of those rights; ultimately it casts doubt on their operativeness as well. ${ }^{51}$

1. Salience (Part I). - Although salience is in some respects the hindmost criterion of legal authority - it follows the other criteria and in fact cannot exist without them - it is a helpful place to begin, for a deficiency of salience is probably the most apparent weakness in the Nuanced version's authority narrative. The problem, in a nutshell, is that while the Nuanced version attenuates the salience problem faced by the Simple version, it does not go nearly far enough toward eliminating it altogether. A legal subject's erroneous disagreement with the substance of a legal right remains dangerously likely to undermine her faith in the authority of that right.

The normative engine of the Nuanced account, remember the source of its operativeness and special force - is a comparative decisional advantage of the constitutional process regarding questions (at least certain questions) of political morality. The criterion of salience therefore requires that a reasonable legal subject be able to recognize this comparative advantage. But a legal subject will have to test the supposed advantage by

\footnotetext{
51 What I describe in this section as deficiencies in salience and operativeness I have described elsewhere as a lack of "content-independence." See PETERS, supra note 12, at 41-44. As I suggested in Part II.E above, I now believe that what is usually called "content-independence" is in fact the conjunction of the three properties I have labeled operativeness, source-dependence, and salience. See supra notes 16-20 and accompanying text. I argue below that two of those properties (salience and operativeness) are not adequately accounted for on the Nuanced Substantive Justification..
} 
subjecting it to her own moral judgments - including her judgments about particular cases to which a constitutional right applies. The greater a legal subject's disagreement with the substance of a right, the less likely she is to recognize the comparative decisional advantage of the process that produced that right; and thus the less likely she is to acknowledge the authority of the right.

To illustrate this phenomenon, consider again the choice faced by our hypothetical chief executive, George, who must decide whether to obey constitutional right $R$, which would forbid him to authorize warrantless surveillance of terrorism suspects. On the Nuanced Substantive Justification, George's reason to obey $R$ depends on a comparison between, on the one hand, George's own decisional capacity absent $R$ (a considerable one, given the vast array of information and opinions at George's disposal), and on the other hand the decisional capacity of the process, $P$, that generated $R$. If the decisional capacity of $P$ with respect to the issue at hand is greater than the decisional capacity of George et al., then the Nuanced account gives George a reason to obey $R$, even if he thinks doing so will not produce a morally desirable outcome.

Suppose for the sake of argument that $P$ - which (let us stipulate) combines, in Hamiltonian fashion, an extraordinarily participatory and deliberative framing procedure with a politically independent process of case-by-case adjudication - does in fact, by virtue of these qualities, have a comparative decisional advantage over George's own unalloyed judgment. And let us further suppose that as a result, $R$ possesses the qualities of operativeness, special force, noncoerciveness, and sourcedependence that are required for legal authority. One criterion of effective authority remains to be established: That authority must be salient, that is, it must be capable of being recognized by a reasonable legal subject. 
So let us suppose that George is in fact a reasonable legal subject. As such, George is unlikely simply to take $R$ 's claim of authority for granted. The stakes are incredibly high, and $R$ is telling George not to do something he strongly believes should be done in the interest of national security. The fact that $R$ claims legal authority does not make it so - George, after all, might find a similar claim scrawled on the proverbial cocktail napkin - and surely George has a responsibility to make a reasonable evaluation of $R$ 's supposed authority before blindly deciding to defer to it. 52

How will George, as a reasonable legal subject, assess the supposed legal authority of $R$ ? What evidence will be relevant to $R$ 's claim of authority? Some of that evidence will flow from the nature of the process, $P$, that generated $R$. So George might examine $P$ for signs of comparative decisional advantage regarding the kind of moral choice she must now make - perhaps for the features identified on Hamiltonian accounts, such as the special deliberativeness of the framing that originated $R$ and the political insularity of the adjudicative process that has refined it. ${ }^{53}$ If George is convinced that these kinds of proce-

\footnotetext{
52 Two quick points in this regard. First, the strength of the case for probing the question of a legal norm's supposed authority will vary depending on, among other things, the cost and the risk of erroneous obedience. Picture a posted 65 -mph speed limit. Few drivers will think it worthwhile to pause and assess whether the speed limit's claimed authority actually exist, in part because the cost of erroneously acknowledging that authority are likely to be low: Rarely will much harm be done by driving a few miles per hour slower than one thinks ideal. But things may well be different when the legal norm in question is a constitutional right claiming the authority to prohibit some seemingly important policy.

Second, remember that George's assessment of $R$ 's supposed authority cannot take account of possible sanctions for disobeying $R$; true legal authority must be noncoercive. So, while George may well consider the likelihood of sanctions both formal and less so - the possibility of impeachment, the effects on his reelection bid, his place in the history books - in deciding whether ultimately to obey $R$, he cannot consider it in deciding whether $R$ actually possesses the legal authority it claims.

${ }^{53}$ None of this is to assert that George will engage in a comprehensive, $a b$ initio process of interrogating the grounds of a constitutional right's supposed authority in every case in which he is faced with one. Even thoughtful legal subjects are likely to form their views about the grounds of legal authority over time, based upon the gradual accumulation of disparate bits of evidence, perhaps not entirely self-
} 
dural elements exist and that they are likely to confer a decisional advantage on $P$, he will have reason to attribute to $R$ the authority it claims.

Now of course George might be mistaken in his evaluation of these procedural questions. But the possibility of mistaken judgment by a legal subject is not, by itself, a threat to an account of legal authority. In an imperfect world, no account of authority will be immune to some degree of human error on the part of legal subjects, even reasonable ones. The degree of error affecting any actual system will be largely a matter of contingent sociological facts. The efficacy of an account of legal authority will be jeopardized only if it inevitably generates an unacceptable rate of error when applied to any given system. Any my argument here is that the Nuanced Substantive Justification inevitably generates an unacceptably high rate of error, even when applied to a legal system consisting entirely of reasonable legal subjects.

This problem arises because a reasonable legal subject like George almost certainly would go beyond an evaluation of the purely procedural aspects of $P$. In assessing the question of $P$ 's supposed comparative advantage, surely George will want to know, not just what $P$ looks like, but also what $P$ has done what results or outcomes or states of affairs have resulted in the past from the rights generated by $P$. The supposed point of obeying a constitutional right like $R$, after all, is $P$ 's superior capacity to promote morally good states of affairs. Whether the states of affairs promoted by $P$ in the past have in fact been morally good thus is an obviously material question.

So George will look to the past results of deferring to rights generated by $P$. But of course George cannot magically assess those results with god-like omniscient judgment. His evalua-

consciously. But it is useful as an illustration to imagine our hypothetical chief executive performing this inquiry more or less from scratch in this particular instance. 
tion of the moral quality of these results (which of them were better, which were worse, whether on the whole the results were good or bad) will be the product of his own unalloyed moral reasoning - the same moral reasoning that, on the Nuanced account, is by hypothesis inferior to the judgment embodied in $P$. In other words, George will be using his own moral judgment to determine, in part at least, whether his own moral judgment is inferior to that of $P$.

Now we can begin to discern the problematic boot-strapping attempted by the Nuanced account of legal authority. On that account, the legal authority of constitutional rights is premised on the comparative decisional advantage of the process $(P)$ for producing those rights vis-à-vis the moral judgments of those who, like George, supposedly are bound by them. But legal subjects like George cannot perceive this authority without wielding their own (by hypothesis inferior) moral judgments. Thus the effectiveness of the Nuanced account is imperiled by the very phenomenon the account seeks to avoid.

Again, the problem here is not simply that legal subjects like George might make mistakes in deciding whether a constitutional right is authoritative. The problem is that the Nuanced account is premised on the inevitability of precisely this sort of mistake. The whole point of constitutional rights, on that justification, is to remove certain issues from the (by hypothesis inferior) moral judgment of legal subjects and decide them by the (by hypothesis superior) moral judgment of the constitutional process. The relative inferiority of the legal subject's judgment is at the foundation of the account. So the same phenomenon that gives constitutional rights their authority (on the Nuanced account) also threatens the efficacy of that authority by reducing the capacity of legal subjects to recognize it.

And note what I am not arguing here. I am not claiming that the Nuanced Substantive Justification's account of legal authority is faulty because legal subjects might erroneously 
disobey constitutional rights. That possibility is, I believe, endemic to (plausible) accounts of legal authority, whatever their particulars. Barring an absolutist account of legal authority one holding that valid law imposes an absolute duty of obedience, trumping all nonlegal considerations ${ }^{54}$ - there will always be a danger that legal subjects will undervalue the claims of legal authority, overvalue the competing considerations, and thus erroneously disobey even authoritative law. (Indeed this risk probably is inevitable even on an absolutist account, as any given legal subject might erroneously deny her absolute duty to obey the law.) What is problematic about the Nuanced account, rather, is the endemic likelihood that even reasonable legal subjects will erroneously deny the legal authority of constitutional rights - thus entirely vitiating what should be a prima facie duty to act as the law requires (and thereby greatly increasing the corresponding risk of erroneous disobedience of the law).

To sum up so far, then: The Nuanced Substantive Justification relies on the premise that the reasonable legal subject's unalloyed moral judgment is inferior to the judgment embodied in the constitutional process. But the reasonable legal subject will test this claim by assessing the past results of that process using his own (inferior) moral judgment. If his assessment is erroneous - as the account stipulates it is likely to be - then his evaluation of the authority of constitutional rights might be erroneous as well. The salience, and thus the effective authority, of constitutional rights will be undermined by the very problem the Nuanced Substantive Justification is supposed to avoid.

But the problem gets worse.

2. Salience (Part II). - The problem gets worse because, in assessing $P$ 's claim to a comparative decisional advantage, a 44-47.

${ }^{54}$ I argue against such an absolutist account in PETERS, supra note 12, at 33-36, 
reasonable legal subject like George is unlikely to be satisfied with looking at the past results of $P$. Those results will be relevant, to be sure - they will suggest whether $P$ really is competent at generating morally desirable results - but they are likely to be relevant by analogy at best. Few prior cases will be on all fours with the case George now faces, and so P's performance in those past instances - to be precise, the states of affairs resulting from obedience to the rights generated by $P-$ will be suggestive but probably not conclusive evidence of $P$ 's likely performance in the case at hand. Surely the most direct evidence on that question is in fact the state of affairs likely to result from obedience to $R$ (as a product of $P$ ) in the case at hand.

So George will ask what state of affairs is likely to result from obedience to $R$ in his case; and he will ask whether that state of affairs is morally desirable. And of course he can only answer these questions through the filter of his own fallible moral judgment. George, then, might turn out to be wrong in his determination of whether obeying $R$ in his case will promote a morally desirable state of affairs. (Indeed, it is precisely this possibility that justifies the authority of constitutional rights in the first place on the Nuanced Substantive account.) Remember, too, that George is in this fix to begin with because his own moral judgment, pre- $R$, is counseling him to do something (to authorize the surveillance) that $R$ purports to forbid. So it is quite likely indeed that George will conclude, erroneously, that obeying $R$ will not promote a morally desirable state of affairs in this particular case. And this will serve as powerful evidence - more powerful, perhaps, than $P$ 's performance in prior cases - that the claim of comparative decisional advantage embodied in $R$ is vacuous, and thus that $R$ lacks authority over George.

The threat to salience revealed by this example is, I think, especially dangerous. It arises from the legal subject's judg- 
ment about morally desirable results in the particular case he faces, and it is precisely this phenomenon - the subject's exercise of his (possibly erroneous) judgment in the particular case - that justifies constitutional rights on the Nuanced account. And because of the obvious, perhaps overriding materiality of this particular bit of evidence (evidence regarding the result in the case at hand) to the question of comparative decisional advantage in that case, the legal subject seems likely to give it special (perhaps overriding) weight in his assessment of that question. It also seems likely that the stronger the subject's disagreement with the right in that case - the less morally desirable the subject thinks the result of obeying the right will be - the weaker the right's claim to authority will become in the subject's view. A process that gets it so wrong in such an important case can hardly be reliable generally on moral matters. Or so the legal subject seems dangerously likely to conclude.

We thus face the following difficulty on the Nuanced account: The very danger that account seeks to avoid (the erroneous moral judgment of legal subjects in particular cases) is in fact a threat to the authority of constitutional rights on that account, reducing the likelihood that those rights will be sufficient to meet the danger. A legal subject has reason to obey a constitutional right with which he disagrees, but his reason might be merely theoretical - overwhelmed by the fact of his disagreement. The authority of constitutional rights, on the Nuanced account, threatens to become irrelevant.

And in fact the problem gets worse still.

3. The Aristotelian Difficulty (Part I). - The problem gets worse still because of a well-known flaw in rules, one famously noticed by Aristotle. The flaw manifests itself at two levels on the Nuanced Substantive Justification. It afflicts particular constitutional rights themselves where those rights take the form of a Hartian primary rule - as is almost always the case in actual constitutional practice. More fundamentally, it af- 
flicts the secondary rule posited by the Nuanced account, namely that constitutional rights should be treated as authoritative because they derive from a decisionally advantaged procedure. One result is further attenuation of the salience required for legal authority. An even more devastating result is a breakdown in the very operativeness of constitutional rights.

In his Nicomachean Ethics, Aristotle shared the following insight about rules:

[A]ll law is universal but about some things it is not possible to make a universal statement which shall be correct. In those cases, then, in which it is necessary to speak universally, but not possible to do so correctly, the law takes the usual case, thought it is not ignorant of the possibility of error. And it is none the less correct; for the error is not in the law nor in the legislator but in the nature of the thing, since the matter of practical affairs is of this kind from the start..$^{55}$

Aristotle's insight is simply that rules often have exceptions cases in which, although a rule applies, its application is not justified by whatever justifies the rule. In modern parlance, the problem is that rules typically are overinclusive: 56 They cover cases in which their justification does not exist or is overcome by other considerations. A rule prohibiting the consumption of alcohol by people under age 21 will apply to many teenagers who are mature enough to drink responsibly; a rule prohibiting driving faster than 65 miles per hour will apply in many circumstances in which a greater speed is appropriate, even necessary; and so on. ${ }^{57}$ We might refer to this pervasive imperfection of rules as the Aristotelian Difficulty.

\footnotetext{
55 Aristotle, Nicomachean Ethics, in The BAsic Works of ARISTOTle 935, book V, at 1020 (W.D. Ross trans., Richard McKeon ed., 1941).

56 See the influential discussion in Joseph Tussman \& Jacobus tenBroek, The Equal Protection of the Laws, 37 CAL. L. REV. 341 (1949).

REV. 341 (1949)

57 I survey the causal explanations for the imperfection of rules in PETERS, supra note 12 , at 2-7.
} 
This Aristotelian Difficulty infects the Nuanced Substantive Justification of constitutional rights in two ways. Consider first the fact that constitutional rights typically take the form of Hartian primary rules. In our running hypothetical, $R$ will not be an ad hoc decree directed at the particular circumstances George happens to face, but rather a general rule derived from the language of a canonical text and refined over many years by particular applications in judicial decisions and other instances. The rule embodied in $R$, moreover, will be what Hart called a primary rule: It will (purport to) bind George directly, in his capacity as a legal subject - to require him to act or refrain from acting in a certain way. 58

As a primary rule, $R$ will be justified by considerations like the importance of personal privacy, the avoidance of government tyranny, and the like, and it will appropriately apply in any case in which these considerations outweigh any countervailing ones (such as law enforcement or national security). But, as Aristotle reminds us, $R$ may have exceptions: cases in which it applies but is not justified. There may be some cases in which $R$ forbids a search, for example, where that search would in fact promote law enforcement or protect national security with comparatively little cost to personal privacy or risk of government tyranny. In such cases, the "universal statement" embodied in the rule would not be correct.

Now a problem for the Nuanced Substantive Justification is this: A legal subject like George will, again, have to exercise his own unalloyed moral judgment to determine whether his case $i s$ an exception to the general rule embodied in $R$. Seen in Aristotelian terms, this problem is subtly different from the one discussed above - the phenomenon of George's use of his moral judgment about this case to assess the authority of $R$, or

\footnotetext{
58 Recall my description of the distinction between Hartian primary and secondary rules and its relevance to the authority of constitutional rights in Part II.F. See supra notes 21-30 and accompanying text.
} 
perhaps of all constitutional rights, more generally. Faced with the Aristotelian Difficulty, George will employ his own moral judgment, not simply to identify evidence of the general reliability of $P$ (the process that produced $R$ ), but also to determine whether this particular case is an exception to $R$, quite regardless of whether $P$ on the whole is reliable. George's disagreement with $R$ in this case - his belief that obeying $R$ would not promote a morally desirable result - might be enough to convince him that $R$ lacks authority in this case, even if it is not enough to convince him that $R$ (as a product of $P$ ) lacks authority generally.

This point is a bit conceptually tricky, so allow me to illustrate with a more-detailed description of George's reasoning. As we've seen, George will have to determine for himself whether $R$ really possesses legal authority in the circumstances he faces. So George will look at a number of bits of evidence relevant to this question. First, George will look at the procedural features of the process that generated $R$, process $P$, to determine whether they seem like the kind of procedures capable of producing a comparative decisional advantage. Second (and problematically, as we've seen), George will look at past results generated by $P$ to determine whether those results evince a capacity to promote morally desirable states of affairs. And third (even more problematically), George will look at the likely result of obeying $R$ in this particular case, again to determine whether that likely result supports the proposition that $P$ has a comparative decisional advantage.

Suppose that after working through this reasoning, George remains persuaded (perhaps only by a hair) that $P$ has a comparative decisional advantage, and thus that $R$ possesses legal authority as a product of $P .59$ Now, however, George will make

\footnotetext{
59 It is not out of the question that George would conclude this, despite all the obstacles to his doing so. George's moral assessment of $P$ 's performance in past cases, and of the likely results of obeying $R$ in this case, might be influenced by the
} 
an additional inquiry in response to the Aristotelian Difficulty: He will ask whether, despite its general legal authority, $R$ lacks legal authority in this instance because this instance is an exception to $R$. And George might well conclude that the answer is yes, even though $R$ is the product of a process that, generally speaking, possesses a comparative decisional advantage - and even though $R$ therefore possesses authority in the majority of instances.

Why might he (reasonably) conclude this? Consider the relative decisionmaking posture of George in relation to $P$, the process that created $R . R$ is a general rule created over time by a long string of decisionmakers, none of whom are likely to have considered the particular facts of George's case in making the rule. The framers of the textual provision from which $R$ derives probably did not have George's particular case in mind - indeed it may have been impossible for them to have had it in mind, if they did their work many years earlier, in a very different world that did not include phenomena like electronic surveillance and international terrorism. And while the content of $R$ will have been refined post-framing by case-by-case application, only if one of those cases happens to have been virtually identical to George's case (an unlikely scenario) will it be possible to say that $R$ 's authors had that case in mind when they formed their rule. George may well conclude, in other words, that $P$, however reliable it may be as a general matter, did not consider his particular case in creating $R$.

George also will recognize, on the other hand, that there is a decisionmaker capable of fully considering the particular case

facts that those results have been generated by $P$. If George starts from a belief that $P$ generally is reliable, he might be more inclined to view the results of $P$ as morally desirable than he would have been without this belief. This inclination itself might sweeten his assessment of those results, tempering the countervailing considerations and increasing the likelihood that he will agree with them in substance. It might even cause him to rethink his initial belief that obedience to $R$ in his case would not produce a morally desirable outcome. $P$ and $R$, in other words, might provide an epistemic reason for George to alter his moral beliefs. 
he now faces: namely George himself. George's capacity to take specific account of his particular circumstances (George reasonably might think) constitutes a comparative decisional advantage over $P$, which lacks that capacity - perhaps a very significant comparative advantage. Unlike $P$, after all, George is not handicapped by an inability to foresee the particular situation he now faces. Indeed, George might reasonably conclude that whatever usual properties give $P$ a comparative decisional advantage over George are outweighed, in this instance, by George's uniquely particularistic perspective.

Based on this reasoning, George, as a reasonable legal subject, might reasonably reject $R$ 's claim to legal authority over him in his particular case. He might do so not (or not solely) on the ground that his disagreement with $R$ in this case undermines $R$ 's general claim to legal authority, but rather on the ground that his disagreement with $R$ in this case undermines $R$ 's specific claim to legal authority in this case.

Now it will, again, always be a risk of theories of legal authority that a legal subject will decide, wrongly, to disobey a supposedly authoritative norm in any particular case. But the phenomenon I'm describing here is special in two senses. First, the risk is (again) not simply that George will decide to disobey $R$, but rather that George will decide that $R$ lacks authority over him in this case (and thus that the strongest reason for obedience to $R$ is entirely vitiated). George's conclusion that his case is an exception to $R$ is a conclusion that $R$ should not apply in this case - that $R$ lacks authority in that case - not a conclusion that $R$ applies but nonetheless should be disobeyed.

Second, the risk of erroneous denial of $R$ 's authority is, again, endemic rather than merely happenstance on the Nuanced Substantive Justification. The whole point of that justification, remember, is to avoid subjecting certain important moral decisions to the fallible judgment of the legal subject; the subject's comparative moral fallibility is a premise of 
the account. But thanks to the Aristotelian Difficulty, the question of a constitutional right's authority will, in any given case, be subjected as a practical matter to precisely the fallible judgment the account is supposed to avoid.

Note too that the Aristotelian threat to legal authority is even greater than the threat described in the previous two sections. For one thing, the Aristotelian threat exists without regard to the comparative decisional advantage of the constitutional process generally or to evidence regarding that advantage. George might believe that every single past instance of obeying $R$, even of obeying the products of $P$ more generally, has produced a morally desirable state of affairs, and still reasonably conclude that this case is an exception to $R$. George might even think that his disagreement with $R$ in this instance - his belief that obeying $R$ would not promote a desirable result - is insufficient to disprove $R$ 's authority generally, and still (reasonably) conclude that this case, again, is an exception to $R$. The Aristotelian threat thus is likely to be especially persistent.

And - importantly - the Aristotelian Difficulty threatens not just the salience of constitutional rights, but also their operativeness. We have been indulging the assumption thus far that George's assessment of the authority of $R$ is erroneous. But the Aristotelian Difficulty raises the troubling possibility that a constitutional right may in fact lack authority in any given case. Suppose George is correct that $P$ did not actually consider his specific facts in fashioning $R$ : Neither the framers of the underlying provision nor its subsequent interpreters envisioned those circumstances (perhaps because they could not have envisioned them). And suppose George is therefore correct in concluding that he (with all his resources) is in fact a better decisionmaker in this instance than the process that generated $R$. George's decision to reject $R$ 's authority then would not reflect a lack of salience; it would reflect an actual 
lack of authority (to be precise, a failure to generate an operative reason for George to act). $R$ would lack authority in George's case because the reason justifying that authority - the comparative decisional advantage of the process that created $R$ - simply would not apply.

Of course, the failure of legal authority in any given instance need not entail the wholesale failure of an account of legal authority. It is unlikely that any general account of authority could meet such a perfectionist standard. As it happens, though, the particular normative grounding of the Nuanced Substantive Justification makes it especially susceptible to the challenge posed by the Aristotelian Difficulty.

4. The Aristotelian Difficulty (Part II). - To appreciate the extent of the problem, consider the fact that any given constitutional right is more than just a primary rule governing the conduct of government officials and voters; it also is the product of a secondary rule conferring authority upon the primary rule. Constitutional right $R$ possesses authority (if at all) only because a secondary rule in the applicable jurisdiction says so. And here is the rub: The Aristotelian Difficulty applies not just to $R$ as a primary rule, but also to this secondary rule governing the authority of $R$ as a primary rule. Aristotle tells us that there may be exceptions to the secondary rule conferring $R$ 's authority - cases in which the rule applies but is not justified by whatever considerations justify the rule more generally.

On the Nuanced Substantive Justification, the secondary rule that confers primary authority upon $R$ is justified by comparative decisional advantage: $R$ has authority if (and only if) the process $P$ that generated $R$ has a comparative decisional advantage over the legal subject's unalloyed moral reasoning. ${ }^{60}$ We have seen that this justification might not apply in some

\footnotetext{
60 "If and only if," that is, so far as the justification supplied by the Nuanced account is concerned. It is of course possible that $R$ could lack authority on the Nuanced account but possess it by some other means.
} 
particular cases. What that means is that any given case might be an exception to the secondary rule conferring authority on $R$; in any given case in which $R$ applies, $P$ might not in fact possess a comparative decisional advantage over the legal subject himself, and thus $R$ might not have authority at all.

Again, the failure of legal authority in some cases need not entail the general failure of a theory of legal authority. But the trouble for the Nuanced Substantive Justification is that it hinges entirely on the existence of a comparative decisional advantage. If that advantage is missing from any given case, then the Justification does not hold in that case - the constitutional right in question simply lacks authority in that particular instance. And there is every reason to believe that Aristotelian exceptions will be quite common on the Nuanced Substantive Justification. Constitutional rights typically are expressed by means of a relatively archaic text, in very open-textured language, which is interpreted relatively infrequently by courts responding to their own particular circumstances and doing so by means of their own open-textured language. Under these conditions, it will be relatively unusual for the constitutional process to have taken specific account of the exact circumstances that the legal subject faces in any particular instance (or even of loosely analogous circumstances). To the extent the constitutional process has not considered the precise facts at hand, its claim of a comparative decisional advantage vis-à-vis the legal subject becomes correspondingly less plausible. Thus there will be a strong likelihood that any given case is an exception to the secondary rule conferring authority on constitutional rights. ${ }^{61}$

\footnotetext{
61 Joseph Raz makes a similar point:

To assume that expertise gives lawmakers timeless authority is to assume that either no advance in knowledge in the relevant area or no advance in its spread is likely, or both. Such advances would negate the expertise of the old lawmakers relative to new experts (new advances in knowledge) or
} 
It seems probable, then, that gaps in the actual (and not just in the perceived) authority of constitutional rights will be endemic on the Nuanced account. The account depends on a comparative advantage that, the Aristotelian Difficulty suggests, will be lacking in many, perhaps even most cases to which constitutional rights apply. And so in addition to the high cumulative risk that even reasonable legal subjects will wrongly deny the authority of constitutional rights, we must add a high risk that those rights will in fact lack authority.

$* * *$

Here, then, is where we stand so far. The Nuanced Substantive Justification runs into trouble, as an account of legal authority, because it depends on the general validity of the proposition that constitutional processes have a comparative decisional advantage over constitutional subjects. That proposition produces internal tension in the account, because it suggests that legal subjects frequently (indeed endemically) will err in their assessments of constitutional authority. And its generality seems difficult if not impossible to sustain in the face of the Aristotelian Difficulty, which gives strong reason for skepticism that the supposed comparative advantage actually will exist in very many cases.

In other words, the Nuanced Substantive Justification, while an improvement over its Simple cousin, nonetheless leaves much to be desired as an account of the legal authority of constitutional rights.

relative to the population at large (the spread of knowledge). Either would denude them of legitimate authority insofar as it is based on expertise.

Joseph Raz, On the Authority and Interpretation of Constitutions: Some Preliminaries, in Constitutionalism: Philosophical Foundations 152, 168 (Larry Alexander, ed. 1998). 
IV. Procedural Justifications as Accounts of Legal AUTHORITy (WITH SPECIAL ATTENTION TO "REPRESENTATIONREINFORCEMENT")

The central problem with Substantive justifications of constitutional rights, when it comes to legal authority, is their dependence on the moral desirability of the states of affairs that result from obeying rights. If obedience would not produce a morally good result, the reason for obedience is undermined; and so a subject's disagreement with the result erodes her faith in the right's authority.

Procedural justifications can escape this problem by resting the authority of constitutional rights, not on their capacity to generate morally desirable states of affairs, but rather on their capacity to avoid or resolve disputes about which states of affairs are morally desirable. Writ large, Procedural justifications hold as follows: Constitutional rights are normatively justified as means of avoiding, resolving, or mitigating certain types of disagreements about which outcomes are morally best.

Below I examine Procedural justifications in more detail through the lens of their best-known exemplar, the "representation-reinforcement" approach of John Hart Ely and Carolene Products Footnote Four (to which I will refer as the Representation-Reinforcement Justification). Note first, however, the basic mechanics by which Procedural justifications might avoid the self-eroding account of authority offered by their Substantive rivals. The core problem with Substantive accounts is that moral disagreement with the outcome of obeying a right serves as a reason, perhaps quite a strong one, not just to disobey the right, but to deny its authority altogether. But on Procedural accounts, disagreement with outcomes need not serve as a reason to deny the authority of constitutional rights. One might believe the outcome of obeying a right will be morally atrocious, and still have (good) reason to obey the right - namely that doing so will avoid, resolve, or mitigate a dispute. The 
central insight goes back at least to Hobbes:62 Peacefully settling disputes can be a powerful reason to obey the law even when one disagrees strongly with what the law commands.

To illustrate this idea briefly, consider again our hypothetical chief executive, George. Assume George believes that the substantive outcome of obeying constitutional right $R$ - refusing to authorize the warrantless surveillance - is less morally desirable than the alternative. But suppose George also believes that obeying $R$ would promote or preserve the settlement of an important and costly dispute - namely a disagreement over the proper balance between national security and civil liberties in cases like these - and that disobeying $R$ would prevent or destroy that settlement. George now has a reason to obey $R$ despite his disagreement with the substantive result of doing so; his reason is the desirability of resolving or avoiding the dispute that $R$ has settled or may settle.

I will explore these conceptual mechanics more fully below, but for now let me highlight three important aspects of the basic account of legal authority that Procedural justifications embody. The first involves some clarification of the notion of an "outcome" or "result" or "state of affairs" produced by obedience to a constitutional right. To resolve a dispute, or to avoid or mitigate a dispute or preserve an existing resolution of it, may of course be an "outcome" of obeying a right; and in this sense Procedural justifications depend on "outcomes" just as Substantive justifications do. But Procedural and Substantive justifications nonetheless depend on very different sorts of outcomes. Substantive justifications depend on the outcome that follows from the content (or substance) of the right in question; 63 the important thing, on a Substantive account, is what

\footnotetext{
62 See generally Thomas HobBes, Leviathan (C.B. Macpherson ed., 1968) (1651). For a description of Hobbes's general theory of legal authority as a procedural or "dispute-resolution" account, see PETERS, supra note 12, at 57-61.

63 In this sense the familiar terminology of "content-independence" captures something important about the concept of legal authority, despite being misleading
} 
the right tells people to do (e.g., to refrain from authorizing warrantless surveillance). It is that thing - that particular "outcome" or "result" or "state of affairs" - whose moral status matters on Substantive justifications. By contrast, Procedural justifications depend on the outcome that follows from the existence of the right in question; the important thing, on a Procedural account, is that the right tells people to do something. It is the outcome of obeying the right, whatever it tells one to dothat is, the resolution or avoidance of a dispute that occurs when the right is obeyed - whose moral status matters on the Procedural account. Unfortunately language fails us here; there is no pithy way to signal the distinction between these two senses of "outcomes." 64 So I will continue to use the terminology of "outcomes" or "results" or "states of affairs" to describe the lynchpin of Substantive justifications, and the terminology of "dispute-resolution," "dispute-avoidance," and the like to describe the crux of Procedural justifications.

Second, it is important to focus here on precisely what I am claiming: that Procedural accounts can avoid the internal tensions in the accounts of legal authority offered by Substantive justifications. I am not claiming that Procedural accounts can foreclose justified disobedience of constitutional rights; as I have suggested several times already, I very much doubt that any account of legal authority can do this. ${ }^{65}$ (Of course Procedural accounts will have be prove capable of generating a strong enough reason for obedience to constitute a prima facie duty or something close to it.) Nor am I claiming that Proce-

in the ways I suggest above. See supra note 7; supra notes 16-20 and accompanying text. A legal norm whose supposed authority depends on its content - on the moral status of what it commands - is, for that reason, unlikely to be effectively authoritative, for the reasons discussed in Part III. "Content-independence" - a duty of obedience resting on something other than the content of a legal norm - thus is a shorthand way to describe a set of necessary components of legal authority.

64 At least I have not been able to identify one, although I am of course open to suggestions.

65 See supra note 12; supra note 54 and accompanying text. 
dural accounts can prevent erroneous disobedience of constitutional rights, which will (again) be a risk of any account of legal authority intended to apply to actual human beings. (But Procedural accounts - of course - will have to avoid the sort of selffulfilling lack of salience that characterizes their Substantive rivals.) I am claiming only that Procedural justifications can fare better as coherent accounts of legal authority than Substantive justifications can.

Third, just as Substantive justifications bear the burden of persuasively explaining why the results of obeying constitutional rights are likely to be morally superior to the results of disobeying them, Procedural justifications bear the burden of persuasively explaining why obedience of constitutional rights is more likely than is disobedience to avoid, resolve, or mitigate a dispute. Below I will describe the particular explanation in this regard offered by the Representation-Reinforcement version of the Procedural justification. But I will not defend the persuasiveness of that justification on its merits (just as I did not assess the persuasiveness on its merits of the Hamiltonian version of the Substantive justification). Instead I will use Representation-Reinforcement to illustrate how a Procedural account, whatever its merits in other respects, might avoid the conceptual pitfalls of Substantive accounts.

\section{A. Representation-Reinforcement as a Procedural Justification}

In Democracy and Distrust, John Hart Ely mounted an argument against the use of judicial review to "discover fundamental values" - moral truths that, in the revealingly insouciant words of Ely's chief target Alexander Bickel, "qualify as sufficiently important or fundamental or whathaveyou to be vindicated by the Court against ... values affirmed by legislative acts."66 Ely rejected such a quest as antidemocratic, de-

66 ELY, supra note 3, at 43 (quoting BICKEL, supra note 25, at 55). 
volving as it inevitably does (in Ely's view) to the imposition of whichever "values" a given majority of Supreme Court Justice happen to think are "fundamental."67 Persistent doubts about the legitimacy of judicial review - including Bickel's own, near the end of his life ${ }^{68}$ - often can be traced, Ely contended, to the irreconcilable tension between this fundamental-values approach and the realities of moral indeterminacy and moral disagreement. The problem, Ely argued, was that fundamentalvalues theorists were looking for judicial-review justifications in all the wrong places. "No answer is what the wrong question begets," Ely scolded, flinging Bickel's own admonishment back at him. ${ }^{69}$

Ely addressed his critique to an audience of institutional designers, more or less, not of legal subjects; he did not consider its implications for the problem of legal authority. But his argument can be recast in authority-centered terms, as an attack on Substantive justifications of constitutional rights. A defense of judicially enforced rights as necessary to promote "fundamental values" - a form of Substantive justification - will run smack into the fact of disagreement about what those values are, how best to promote them, and indeed whether they exist at all. Legal subjects who disagree with the particular conception of "values" adopted by the Court in interpreting and applying constitutional rights will (on on a fundamental-values approach) have little reason to honor those decisions. Their quest for constitutional authority, then - for reasons to obey constitutional rights - will turn up "no answer."

Ely's critique thus paralleled (quite self-consciously) the evolution of the Court's own thinking about rights between, rough-

\footnotetext{
67 See id. at $43-72$.

68 Ely points to Bickel's last two books, including the posthumously published The Morality of Consent, as evidence of Bickel's doubts. See id. at 71-72 (citing Alexander Bickel, The Supreme Court And the Idea of Progress 177 (1970, and Alexander Bickel, The Morality of Consent 3-5 (1975)).

69 Id. at 43 (quoting BICKEL, supra note 25, at 103); see also id. at 72.
} 
ly, its decision in Lochner v. New York ${ }^{70}$ and its New-Deal rejection of "Lochnerism." The Lochner Court's assertion of "the right to purchase and to sell labor" as a sort of a priori truth ${ }^{71}$ can be understood as an example of the Substantive approach a confidence in the Court's mandate to pursue moral truths through the vehicle of constitutional rights. The eventual crisis of public faith in the Court's legitimacy, crystallized in FDR's "Court-packing" plan, ${ }^{72}$ might be interpreted as an erosion in the perceived authority of a Court so insistent on pursuing a particular, contested vision of political morality. And the Court's adoption, mid-New Deal, of a "hands-off" rationalbasis approach to "substantive" due process ${ }^{73}$ might be seen as belated acknowledgement of the Substantive justification's fatal flaws as an account of constitutional authority.

Rather than reject the idea of judicially enforced constitutional rights altogether, the New Deal Court, and later Ely in considerably more detail, offered an alternative to the Substantive justification. Their "Representation-Reinforcement" approach $^{74}$ justifies constitutional rights, not as paths to the best substantive outcomes, but as means of resolving disputes about

70198 U.S. 45 (1905).

71 See id. at 53-54.

72 There are of course many accounts of the events surrounding the Courtpacking proposal. For two useful ones of recent vintage, see BARRY FRIEDMAN, THE Will of the People: How Public Opinions Has Influenced the Supreme Court and Shaped the Meaning of the Constitution 212-36 (2009), and Noah Feldman, Scorpions: The BatTles and Triumphs of FDR's Great Supreme Court Justices 103-14 (2010)

73 See, e.g., United States v. Carolene Products Co., 304 U.S. 144, 152 (1938):

$[R]$ egulatory legislation affecting ordinary commercial transactions is not to be pronounced unconstitutional unless in the light of the facts made known or generally assumed it is of such a character as to preclude the assumption that it rests upon some rational basis within the knowledge and experience of the legislators.

74 Ely used the term "representation reinforcement" to describe the approach (see ELY, supra note 3, at 87-88), and that has become the standard label for it. See, e.g., Michael C. Dorf, The Coherentism of Democracy and Distrust, 114 YALE L.J. 1237 (2005) (using the term "representation reinforcement" more than thirty times to describe Ely's theory). 
what those outcomes should be. On this view, constitutional rights are responses to two categories of endemic dysfunction in democratic politics. First, the people momentarily holding power in a democracy - electoral majorities and their representatives in government - have strong incentives to rig the democratic system so they remain in power, by enacting (in the Carolene Products Court's words) "legislation which restricts those political processes which can ordinarily be expected to bring about repeal of undesirable legislation." 75 Expanding on Ely and Footnote Four, we might identify two main subcategories of worry here: ${ }^{76}$ agency failure, in which legislators or other government officials seek to protect their positions at the expense of the citizenry; and, to borrow James Madison's term, majority faction, by which a majority of citizens, "united and actuated by some common impulse ... of interest," ${ }^{77}$ seeks to entrench its preferences against displacement by some future majority.

Second, even absent some formal impediment to political change, democratic majorities might be misled by "prejudice against discrete and insular minorities ... which tends seriously to curtail the operation of those political processes ordinarily to be relied upon to protect [political] minorities." 78 The worry here is that even where the formal mechanics of the democratic process remain intact - everyone has full and equal rights of

\footnotetext{
75304 U.S. at 152 n4. Forgive me for remarking that Footnote Four features arguably the highest ratio of doctrinal influence to prose craftsmanship of any textual passage in the history of Supreme Court jurisprudence. See also ELY, supra note 3, at 103 ("Malfunction occurs when ... the ins are choking off the channels of political change to ensure that they will stay in and the outs will stay out ...."); and see generally id. at 105-34 (describing this type of dysfunction and the constitutional response to it).

76 Neither Ely nor the Carolene Products Court were scrupulous about distinguishing between these two related but separate categories of political entrenchment. For a more complete discussion, see PETERs, supra note 12, at 255-66.

77 Federalist No. 10, in The Federalist PAPERs, supra note 42, at 123. A reading of this and other entries in The Federalist Papers (particularly No. 51) reveals that strains of the procedural justification can be traced back to the Founders.

78 Carolene Products, 304 U.S. at 152 n4.
} 
political participation - some irrational bias (some "common impulse of passion" in Madison's phrase ${ }^{79}$ ) will prevent certain political minorities from getting a fair hearing in the public debate. Ely, who focused much of his attention on this concern, of course had in mind the case of racial prejudice, 80 but the problem might also arise in other contexts frequently inflected with irrational bias:81 gender, religion, alienage, sexual orientation, and so on. Indeed the problem might extend even to cases of rational bias - circumstances in which political majorities share some "common impulse," not of blind "passion," but of calculated "interest" that closes their ears and their minds to the arguments of those who do not share that interest. ${ }^{82}$

According to the Representation-Reinforcement account, the occurrence of these types of democratic dysfunction threatens the efficacy of democracy as a dispute-resolution mechanism. Consider again our warrantless-surveillance hypothetical. It might be that the authorization of such surveillance would be appropriate - morally desirable - all things considered; or it might be that it would sacrifice too much personal privacy and pose too great a risk of government tyranny to be worth the candle. But the "ins" (to use Ely's term) who currently hold power - our chief executive, George, for example - are unlikely to be trustworthy arbiters of this debate, precisely because they stand to benefit so substantially from one particular resolution of it. And even if George and his advisors can in fact be trusted to resolve the debate fairly, they are unlikely to be perceived as trustworthy by those affected by their decision.

On the Representation-Reinforcement approach, this is where judicially enforceable constitutional rights come in. To

\footnotetext{
79 Federalist No. 10, supra note 77, at 123.

80 See the extensive discussion in Chapter 6 of ELY, supra note 3, at 135-79.

81 As Ely of course acknowledged. See ELY, supra note 3, at 140-41 ("There is nothing in the reasoning that establishes the relevance of unconstitutional motivation that limits it to cases involving racial discrimination.")

82 For discussions of this point, see $i d$. at 77-87; PETERs, supra note 12, at 260.
} 
subject this issue to the purview of a constitutional right is to submit it to a process that is not so saliently tainted by selfinterest: decision by electorally insulated judges, who are (relatively speaking) "in a position to objectively assess" these matters, ${ }^{83}$ pursuant to general principles laid down by Framers who have long since passed from the scene and thus have no active stake in the outcome. ${ }^{84}$ Constitutional rights and judicial review thus can offer a more-impartial forum than democratic politics for resolving issues in which the danger, or the perception, of official self-interest is strong.

The same point holds where the perceived threat comes from majority rather than official self-interest. Imagine a debate over legislation that would punish destruction or defacement of certain revered national symbols, like the national flag. ${ }^{85}$ The current political majority is likely to have a horse in that race: Its self-interest, as a majority, in retaining its majority status (and thus its political power) would be furthered by enactment of the law and the resulting deterrence of minority political protest. Giving final say on the issue to the self-interested majority would hardly encourage acceptance of the result by the minority. But giving final say to a nonmajoritarian process interpretation by politically insular judges of a principles established by long-dead framers - might encourage that acceptance.

Finally, consider an issue likely to evoke strongly held "impulse[s] of passion" among a substantial portion of the electo-

\footnotetext{
83 ELY, supra note 3, at 103.

84 Both Ely and the Carolene Products Court emphasized the relative objectivity of federal courts vis-à-vis ordinary democracy; neither mentioned that the constitutional framing process might itself provide an additional measure of impartiality. The impartiality-promoting role of the constitutional framing is my own gloss on the Representation-Reinforcement approach. See PETERS, supra note 12, at 252-55, 274 82. I believe, however, that adding an emphasis on the framing to a focus on judicial review is entirely consistent with the normative and conceptual underpinnings of the Representation-Reinforcement account.

85 See, e.g., Texas v. Johnson, 491 U.S. 397 (1989).
} 
rate: a proposal to consider race in university admissions, ${ }^{86}$ for example, or to use taxpayer dollars to support instruction in religious schools. ${ }^{87}$ The specter of bias might threaten the perceived legitimacy of an ordinary democratic resolution of these issues. That threat might be eliminated or mitigated by subjecting the issues to the relatively apolitical process involved in creating and applying constitutional rights.

These, at any rate, are the tenets of the RepresentationReinforcement defense of constitutional rights. The central idea, again, is that constitutional rights are justified as ways to trigger an extrademocratic, and thus relatively impartial, process for deciding issues that cannot be trusted to ordinary democratic politics. Representation-Reinforcement is therefore a species of Procedural accounts, which justify constitutional rights as means of avoiding, resolving, or mitigating certain types of disputes about how to proceed. Constitutional rights, on that account, carry authority - they impose a prima facie duty of obedience - because, and to the extent that, obeying them will settle some disagreement that cannot adequately be settled by ordinary democratic means.

\section{B. Hamiltonian Accounts as Procedural Justifications}

Before assessing Representation-Reinforcement against the elements of legal authority I catalogued in Part II, I should note that Hamiltonian and neo-Hamiltonian defenses of constitutional rights, which I cast above in Nuanced Substantive terms, ${ }^{88}$ might also be understood as types of Procedural accounts. Hamilton attributed "superior ... authority" to "solemn and authoritative act[s]" of framing and amending a constitution, by virtue of the enhanced deliberativeness and extraordi-

\footnotetext{
86 See, e.g., Grutter v. Bollinger, 539 U.S. 306 (2003); Gratz v. Bollinger, 539 U.S. 244 (2003); Regents of the Univ. of Cal. v. Bakke, 438 U.S. 265 (1978).

87 See, e.g., Zelman v. Simmons-Harris, 536 U.S. 639 (2002); Mitchell v. Helms, 530 U.S. 793 (2000).

88 See supra Part III.B.2.
} 
narily broad participation that typically characterize those acts; 89 Ackerman's ideal of "higher lawmaking" during "constitutional moments" expands on this theme.90 Viewed through a Nuanced Substantive lens, these theories assert that the framing process carries authority because of its special capacity to generate morally desirable outcomes. But one reasonably could see these theories as making a Proceduralist argument instead. It might be that acts of constitutional framing, by virtue of their specially deliberative and participatory character, are better suited than ordinary majoritarian democracy to identify the terms of fair democratic participation; if so, then obeying the results of these "constitutional moments" might promote fairness in ordinary democratic politics. The same might be said for Hamiltonian and neo-Hamiltonian defenses of judicial review as a process specially suited to deciding issues of "principle," "value," or "political justice":91 The supposed advantages of judicial review might contribute, not to better moral reasoning, but rather to more reliable identification of the terms by which democratic processes themselves can fairly engage in moral reasoning. 92

The range of plausible Procedural justifications therefore is not exhausted by Representation-Reinforcement, and indeed many prominent theories might be understood in either Substantive or Procedural terms. One potential implication of my arguments here, then, is that if we want to assess Hamiltonian and similar approaches in their best possible light, we ought to understand them as Procedural accounts rather than Substantive ones whenever it is plausible to do so.

\footnotetext{
89 See Federalist No. 78, supra note 42 , at 440.

90 See ACKERMAN, Foundations, supra note 45.

91 See BICKEL, supra note 25, at 25 ("principle"); $i d$. at 27 ("enduring general values"); EISGRUBER, supra note 4, at 57-59 ("principle"); SAGER, supra note 4, at 19 ("political justice").

92 Elsewhere, I have articulated at some length a Procedural justification of constitutional law that incorporates elements from each of these and other theorists. See PETERs, supra note 12, at 243-348.
} 


\section{Representation-Reinforcement and Legal Authority}

Representation-Reinforcement turns out to be superior to Substantive justifications as an account of the authority of constitutional rights. The key is that RepresentationReinforcement provides a reason to obey a constitutional right that does not hinge on the right's substantive content.

1. Operativeness. - The Simple Substantive Justification, remember, is doomed in part by its rather blatant lack of operativeness. The only reason it provides for action is to promote a morally desirable outcome - a reason that exists, with the same force, absent the constitutional right in question. The Nuanced Substantive Justification avoids this problem, but ultimately it runs afoul of the Aristotelian Difficulty: Whatever comparative decisional advantage exists in the constitutional process becomes attenuated as a right is applied in unforeseen circumstances, and the operative reason to obey is correspondingly diluted.

Representation-Reinforcement avoids both of these problems. It supplies, first of all, an operative reason, namely the benefits of avoiding, resolving, or mitigating the costs of a dispute. Assuming this reason, or complex of reasons, exists at all, it exists separately and independently of a legal subject's reasons to pursue a morally desirable outcome. So our hypothetical chief executive, George, has a reason to obey constitutional right $R$, even if doing so would not promote a morally desirable outcome; 93 that reason is that obeying $R$ will promote the avoidance, resolution, or mitigation of a dispute about what the morally desirable outcome is or how best to promote it. And if, as it happens, obeying $R$ would promote a morally desirable outcome, Representation-Reinforcement gives George an additional reason to obey: Obedience will avoid, resolve, or

\footnotetext{
93 Remember that I mean "morally desirable outcome" in a content-dependent sense that is separate from whatever moral status may apply to the procedures used to generate that outcome. See supra text accompanying note 64 .
} 
mitigate a dispute as well. By separating the reason to obey from the content of the legal right, RepresentationReinforcement avoids subsuming the question of a right's authority within the question of whether the right's content is morally desirable.

What about the Aristotelian Difficulty? Of course Representation-Reinforcement is subject to the Difficulty in the sense that there may be - almost inevitably will be - exceptions to the (secondary) rule that obeying a constitutional right will avoid, resolve, or mitigate a dispute that cannot be adequately resolved democratically. So there may (almost inevitably will) be situations in which a constitutional right $R$ claims authority but in fact lacks it. But the problem with the Nuanced Substantive Justification was not simply that its account of legal authority was subject to exceptions; the problem was that its account of legal authority made widespread exceptions virtually inevitable. The Nuanced account made legal authority contingent on the comparative decisional advantage of the process $P$ that generated a constitutional right $R$ - on the superior capacity of $P$ to identify morally desirable results. Because $P$ was unlikely to have considered the particulars of most cases in which $R$ would apply, however, its claim to a comparative advantage of this sort would, in many or most cases, be implausible.

Not so on the Representation-Reinforcement account. That account's claim of legal authority is that obeying $R$ will avoid, resolve, or mitigate a dispute that cannot adequately be avoided (or resolved or mitigated) by ordinary democracy. And while there surely will be exceptions to this claim, there is no inherent reason to think those exceptions will be endemic. This is because the Representation-Reinforcement account of authority does not turn on the existence of a comparative decisional advantage on moral matters. It turns instead on the existence of comparative impartiality in $P$ - on the notion that $P$ 
can resolve certain kinds of disputes more impartially than ordinary democracy can. And there is no reason why the comparative impartiality of $P$, assuming it exists, is likely to become attenuated in particular cases unforeseen by $P$.

To illustrate this point, suppose that right $R$ - a right against unreasonable searches and seizures, specified over the years to entail a right against warrantless searches except in certain exigent circumstances - was generated in a relatively impartial way as compared to ordinary democratic politics. Its basic underlying principle was authored by framers who are now long gone and thus had no stake in the outcome of current policy debates. And that principle has been refined over time, through case-by-case adjudication, by judges whose relative political insularity has immunized them against the selfinterested motives of the political majority and their elected representatives.

Now suppose a particular situation in which $R$ applies - say, George's decision whether to authorize warrantless surveillance - was not foreseen by any of the decisionmakers who contributed to this (relatively impartial) process $P$ by which $R$ was created. Does this fact in any way undermine $R$ 's claim to legal authority on the Representation-Reinforcement account? It does not; indeed it appears to strengthen that claim. The fact that $P$ did not foresee the particular circumstances to which $R$ now applies may detract from the comparative moral expertise of $P$ relative to George - a significant problem on the Nuanced Substantive account - but it does not detract at all from the comparative impartiality of $P$ relative to ordinary democracy. In fact it may enhance the comparative impartiality of $P$, because it eliminates any chance that the decisionmakers who created $R$ did so in a partial manner, with some interest in the outcome of applying $R$ to this particular case. Decisionmakers who did not foresee this case could not possibly have acted partially with respect to it. 
The Aristotelian Difficulty therefore does not afflict Representation-Reinforcement with the same self-erosion problem it poses for the Nuanced Substantive Justification. Exceptions to the legal authority claimed by Representation-Reinforcement will exist, as they will on any account that makes use of rules. But there is no reason to think those exceptions will prove endemic.

2. Special force. - I suspect a large part of the intuitive appeal of Substantive justifications, and what may be an intuitive suspicion of Procedural ones, has to do with the requirement that a legal norm carry special normative force (a prima facie duty or something like it) in order to qualify as authoritative. Doing what otherwise would be immoral in the name of good procedure might seem drily legalistic at best, callously wicked at worst. How can the goal of good procedure possibly provide a strong enough reason to justify obeying a morally disagreeable law?

I think it can, and I have argued as much in other work. ${ }^{94}$ Here I will limit myself to three brief points. First, influential empirical research suggests that procedure does in fact matter to people in the real world, enough so that people will often obey and even respect laws with which they disagree so long as they believe the procedure that created those laws was sufficiently fair. ${ }^{95}$ Representation-Reinforcement and other Procedural accounts thus have a claim to rest on more than ivorytower wishful thinking.

Second, Procedural justifications as accounts of legal authority generally (not just of constitutional rights) have a long and distinguished pedigree, stretching from Thomas Hobbes in

\footnotetext{
94 See PETERs, supra note 12, at 57-61, 69-105.

95 See generally Tom R. Tyler, Why People Obey the LaW (rev. ed. 2006). A quick Westlaw search on February 27, 2012 turned up 720 articles citing this or a previous edition of Tyler's book in the law reviews alone.
} 
the seventeenth century96 to Jeremy Waldron in the twentyfirst. 97 The notion that people might sacrifice (at least some of) their substantive commitments in the name of procedural concerns is hardly a radical one.

Third, as Hobbes made graphically clear, ${ }^{98}$ it does not require much imagination to see effective legal procedure as a moral imperative. Effective procedure - procedure capable of acceptably avoiding, resolving, or mitigating disputes - may at bottom be all that stands in the way of Hobbes's "Warre of every one against every one":99 A commitment to substantive results above all else would mean that good-faith disputes never get resolved, hardly a recipe for a stable society. The existence of civilization therefore is pretty good evidence that procedure fairly regularly trumps substance.

So it is at least plausible - I think considerably more than plausible - that an account which, like RepresentationReinforcement, rests on the compelling force of disputeresolution can support a prima facie duty of obedience to constitutional rights. Ultimately, of course, there is no analytical way to demonstrate this - only extensive empirical or normative argument, or both, will do - but suffice it to say that a little digging beneath the superficial intuitive suspicion about "procedure" is likely to reveal a deeper, more complex intuitive

\footnotetext{
96 See supra note 62 and sources cited therein.

97 See, e.g., WALDRON, supra note 4, at 232-54.

98 Hobbes famously imagined a world without law:

In such condition, there is no place for Industry; because the fruit thereof is uncertain; and consequently no Culture of the Earth; no Navigation, nor use of the commodities that may be imported by Sea; no commodious Building; no Instruments of moving, and removing such things as require much force; no Knowledge of the face of the Earth; not account of Time; no Arts; no Letters; no Society; and which is worst of all, continuall feare, and danger of violent death; And the life of man, solitary, poore, nasty, brutish, and short.

HoBBES, supra note 62, part I, at 186.

${ }^{99} I d$., part I, at 189.
} 
and experiential understanding about the centrality of procedure to any system of law.

3. Noncoerciveness. - There is not much to say on this point with respect either to Substantive or Procedural justifications. In order for legal norms to be truly authoritative (I've argued), their operativeness and special force must derive from something other than the threat of official sanctions for disobedience. Neither Representation-Reinforcement nor any of the Substantive accounts relies upon the threat of sanctions as its reason to obey constitutional rights. If any of these justifications fails as an account of legal authority, then, a failure of noncoerciveness will not be the culprit.

4. Source-dependence. - Source-dependence is potentially a bigger issue. The Simple Substantive Justification suffers from a palpable failure of source-dependence: Whether the outcome of obeying a constitutional right is morally desirable, and thus whether there is reason to obey the right, depends entirely on the content of the right itself and not at all on its pedigree. At first blush it may appear that RepresentationReinforcement faces the same problem. Isn't the key question on that account - whether obeying a constitutional right will avoid, mitigate, or resolve a dispute - a question that can be answered without regard to the source of the right?

The answer is "yes" only on a happenstance basis. It surely is possible that a "constitutional right" scrawled on our perennial cocktail napkin could be sufficient to resolve a dispute. George, uncertain what to do in the face of disagreement about the warrantless surveillance plan, might decide to obey $R$ just because it is there - because it seems to him that some rule of decision is better than no rule at all. For that matter, George might decide the issue by tossing a coin. Many issues - who buys the first round, what movie to see, which team receives the first kickoff - are in fact decided this way in the real world. 
But this kind of "any rule is better than none at all" approach cannot support an account of legal authority generally, and certainly not an account of the authority of constitutional rights. Many of the disagreements that are subject to law and virtually all of them that are subject to constitutional rights - are too substantial to be resolved by arbitrary or stochastic procedures. George - and those who disagree with him on the merits - are likely to believe the warrantlesssurveillance issue is simply too important to leave to chance; the coin toss, or the cocktail napkin, will not be seen as reliable-enough mechanisms to decide such an important issue. The question of where to strike the balance between national security and individual liberty is vastly different in degree, perhaps even in kind, from the question of who buys the first round or which team kicks off to start a football game. And it seems likely that this will be true of many or most disputes involving constitutional rights - indeed, of many or most disputes involving law generally. ${ }^{100}$

In resolving resolve disputes of this magnitude, the source of the resolution - the nature of the process generating the proposed result - is likely to matter. This point is the essence of Representation-Reinforcement, which values constitutional rights precisely because they are products of a process that is, generally speaking, more impartial than ordinary democratic politics. George's reason to obey $R$ is not simply that it constitutes a solution or a rule of decision, but rather that the rule it constitutes has been forged by a process that he and the other relevant parties can accept as relatively impartial. His reason to obey, in other words, is source-dependent. The same right scrawled on a cocktail napkin would have no claim to his obedience.

\footnotetext{
100 For an extensive argument that stochastic decision-procedures will not be sufficient to support legal authority on a procedural or dispute-resolution account, see PETERS, supra note 12, at 69-81.
} 
It is worth noting that an insufficient concern for sourcedependence is what dooms the particular theory of legal authority offered by Thomas Hobbes, the father of Procedural accounts (or what elsewhere I have called Dispute-Resolution accounts ${ }^{101}$ ) of legal authority. Hobbes, of course, favored absolute monarchy (the seventeenth-century version of dictatorship) as the source of legal norms, because he thought fear of an all-powerful monarch would "keep [men] in awe," stifling disputes before they could begin. ${ }^{102}$ But as Locke later pointed out, a Hobbesian absolute monarch would be, and would be seen to be, a judge in his own case - the most salient form of partiality - and his decrees ultimately would not be accepted by his subjects as fair resolutions of disputes. ${ }^{103}$ Hobbes failed to appreciate fully that the source of legal commands, not just the bare fact of them, is crucial in dispute-resolution.

5. Salience. - The biggest problem with the most persuasive type of Substantive justification, the Nuanced version, is a dearth of salience. In fact salience is a challenge for Representation-Reinforcement as well; I suspect it may be a perennial issue for any plausible account of legal authority. But Representation-Reinforcement at least can offer a better account of salience than the Nuanced Substantive Justification can.

Recall the nature of the salience problem with the Nuanced account: A legal subject's ability to recognize the authority of a constitutional right depends on the exact thing the Nuanced account says the subject is likely to lack, namely good moral

\footnotetext{
101 See generally id.

102 HobBES, supra note 62, part II, at 227; see generally id., part II, at 223-408.

${ }^{103}$ In his Second Treatise, Locke noted that a Hobbesian monarch could "do to all his Subjects whatever he pleases, without the least liberty in any one to question or controle those who Execute his Pleasure." JoHN LOCKe, Second Treatise of Government, in Two Treatises of Government $§ 13$, at 316-17 (Peter Laslett ed., 1960) (1689-1690). This would simply replicate a state of nature, putting the monarch effectively into a state of war with his subjects. See id. §§90-94, at 369-74. The in evitable result would be a "long train of Abuses" by the monarch, leading to civil war - precisely the evil that government, on Hobbes's theory, was supposed to avoid. See id. $\S 225$, at 463 .
} 
judgment about outcomes. The subject will have to use her own moral judgment to assess the comparative decisional advantage of the process that creates constitutional rights - including an assessment of the moral desirability of the outcome in the particular case she now faces. But the entire point of the Nuanced account is that the moral judgment of the legal subject is relatively untrustworthy. So the account sows the seeds of its own demise, or at least of its own weakness.

Is there a similar element of self-erosion in the Representation-Reinforcement account? Representation-Reinforcement holds that ordinary democratic politics - as embodied, say, in George in his capacity as elected chief executive - is likely to be unacceptably partial with respect to certain issues, like whether the benefits of warrantless surveillance by the government are worth its risks. George's partiality flows, in this example, from self-interest - from the potential to use the surveillance as an artificial supplement to George's power, thus helping "keep the ins in and the outs out," to paraphrase Ely. ${ }^{104}$ The promise of constitutional rights, on the RepresentationReinforcement account, is their capacity to avoid or mitigate this self-interest. But won't the same partiality that is likely to affect George's decision on the merits also affect his assessment of whether he is, as compared to the constitutional process, relatively partial? If we can't trust George to resolve the surveillance issue impartially, how can we trust him to impartially resolve the issue of whether he can resolve the surveillance issue impartially?

A minor part of the answer to this worry is as follows. The self-interest that makes us "distrust" George's decision on the merits (to quote the title of Ely's book ${ }^{105}$ ) may in part be self-

\footnotetext{
104 See ELY, supra note 3, at 103 ("Malfunction occurs when ... the ins are choking off the channels of political change to ensure that they will stay in and the outs will stay out ....").

105 See generally id.
} 
conscious: There is a danger that George will knowingly resolve the surveillance issue in a way that serves his interests. His partiality, in other words, may not be inadvertent. But suppose George quite self-consciously decides to disregard constitutional right $R$ because obeying it would hinder his own interests. This would not be a failure of the salience of $R$ 's authority; rather, it would be an intentional, bad-faith disobedience of $R$ despite (and with knowledge of) its authority. So, to the extent our distrust of George's decision on the merits is motivated by the worry of intentional self-dealing, that worry will not undermine the salience of $R$ on the RepresentationReinforcement account, though of course it will create a practical problem for the implementation of $R$.

This is only a minor part of the answer, however, because we may have good reason to distrust George's decision on the merits quite apart from the risk of intentional self-dealing. Selfinterest and other forms of partiality might invade our decisionmaking without our being aware of it, and if this is the case with George, then the same bias that threatens the integrity of his decision on the merits also seems likely to threaten his assessment of $R$ 's authority. George's self-interest might lead him to erroneously deny the comparative impartiality of the process that produced $R$. And that seems like a threat to salience.

In fact it is not, at least not by itself. There are two important points to be made here. First, in order for a legal subject like George to properly recognize the authority of a constitutional right on the Representation-Reinforcement account, he does not need to accurately assess the comparative impartiality of the constitutional process vis-à-vis the democratic process of which he is a part. What he needs to accurately assess, rather, is others' perceptions of the comparative impartiality of the constitutional process vis-à-vis the democratic process of which he is a part. On Representation-Reinforcement, constitutional 
rights are justified if obeying them will better resolve (or avoid or mitigate) a dispute over certain issues than relying on ordinary democratic politics. This will be the case if those bound by a decision - those who disagree with it on its merits - believe the decision was made relatively impartially. It is these beliefs about the impartially of the process, therefore - not the actual impartiality of the process - that the legal subject (like George) must be able to gauge with reasonable accuracy.

And the fact that George is partial with respect to the question on its merits - the question whether to authorize the surveillance - need not make George partial with respect to the question of others' beliefs. Indeed, even if George turns out to be partial with respect to the procedural question of comparative partiality - the question whether in fact he is more partial than the process that generated $R$ - he may be entirely impartial on the separate question of others' beliefs regarding the procedural question of comparative partiality. And it is this separate question that ultimately determines $R$ 's authority.

Suppose, then, that George's partiality leads him to favor the surveillance on its merits. And suppose the same partiality leads him, erroneously, to conclude that the constitutional process, $P$, that generated $R$ is no less partial on the merits than he is. It is entirely possible that George nonetheless will conclude, correctly, that most others (other government officials, members of the public) believe that $P$ is less partial on the merits than he is. And if he concludes this, he will recognize correctly - the authority of $R$ in his case. His comparative partiality, a premise of Representation-Reinforcement, will not have tainted his judgment with respect to the authority of $R$.

Note how these analytics distinguish RepresentationReinforcement from the Nuanced Substantive Justification. The latter in essence requires a legal subject to exercise his (by-definition) faulty judgment to assess the claims of legal authority. But the former does not; a legal subject can assess the 
claims of legal authority without bringing to bear precisely the partiality that the account seeks to avoid. Judgment regarding the merits of the dispute is crucially distinct from judgment regarding the means of resolving the dispute.

The first crucial point, then, is that partiality with respect to the merits of a disputed question does not by itself threaten salience. The second point is an extension of this first one: It will be obvious even to a (by-definition) partial legal subject like George that the decision to obey a constitutional right with which one disagrees is, and will be perceived as, an impartial act. Suppose again that George's partiality leads him to favor the surveillance on its merits, and also to erroneously deny the comparative impartiality of $R$ as a decision of the issue on its merits. Even so, George can hardly fail to realize that submitting to $R$ anyway - deciding to obey $R$ despite his disagreement with its merits, despite even his disagreement with its relative impartiality - will be seen as an impartial decision. After all, the very fact of his choosing to obey $R$ is a saliently impartial resolution of the dispute on the merits. Clearly such a decision would not have been influenced by George's own partiality, as it would generate an outcome opposite to the one George prefers. And certainly George will understand this - will see that his deference to $R$ will be seen as impartial by others - despite his partiality on the merits of the issue. So, if George accepts the basis of legal authority that Representation-Reinforcement asserts, he will have a strong reason to obey $R$ despite erroneously denying its relative impartiality. The fact of $R$ 's authority, that is, will be salient to George, even though the complete ontology of that authority will not be.

This point reveals an interesting and potentially valuable aspect of the authority of constitutional rights on the Representation-Reinforcement account: That authority is selfreinforcing. If citizens and officials in a society come to believe that constitutional rights generally are authoritative because 
of their comparative impartiality vis-à-vis democratic politics, then obedience of those rights will itself come to be seen as an impartial act - even if the claim of comparative authority is obscured, or indeed unjustified, in any given case. Part of the point of obeying constitutional rights then will be simply the fact of obeying them; that fact alone will contribute to the resolution, avoidance, or mitigation of disputes. Constitutional subjects thus will have good reason to obey constitutional rights even where they deny (correctly or incorrectly) the comparative impartiality of the process that produced them.

Note that this phenomenon, too, has no parallel in the Nuanced Substantive Justification. On the Nuanced account, an erroneous rejection of the comparative decisional advantage of the constitutional process in any given case leaves no remaining good reason for obeying a right. But on Representation-Reinforcement, erroneous rejection of the comparative impartiality of the constitutional process leaves an additional reason for obedience: the potential that the decision to obey a right will itself help resolve a dispute.

So Representation-Reinforcement can provide a better account of salience than the Nuanced Substantive Justification can. This is not to say that its account of salience is perfect. It seems possible that a participant in democratic politics like George might be so partial in a given case that he is blind to the dispute-resolving advantages of obeying a constitutional right. But it also seems unlikely that this will occur in a great many cases - and certainly less likely than on the Nuanced Substantive account, whose very premise seems destined to undermine its salience.

$* * *$

As a Procedural account, Representation-Reinforcement divorces the reason to obey a constitutional right from the content of that right. This maneuver makes the moral status of 
particular outcomes irrelevant to the authority of rights, thus escaping the failure of operativeness that threatens Substantive accounts. It also, crucially, makes disagreement or confusion over particular outcomes irrelevant to a legal subject's assessment of the authority of rights, reinforcing the salience of that authority. And by tying dispute-resolution to the nature of the process generating constitutional rights, RepresentationReinforcement provides the source-dependence that legal authority demands. Representation-Reinforcement therefore seems capable of avoiding the foundational weaknesses that threaten the authority of constitutional rights on Substantive justifications.

\section{Conclusion: Fleeing Substance}

Even staunch defenders of constitutional rights have criticized the Ely/Footnote Four Representation-Reinforcement approach as a Pollyannish "flight from substance," resting on an unsustainable distinction between "substance" and "procedure" and offering a myopic caricature of actual American constitutional practice. ${ }^{106}$ I think these critiques, on their merits, are overblown, as I have argued elsewhere. ${ }^{107}$ But my point in this

106 See, e.g., Laurence H. Tribe, The Puzzling Persistence of Process-Based Constitutional Theories, 89 YALE L.J. 1063 (1980), reprinted in LAURENCE H. TRIBE, Constitutional Choices 9 (1985) (retitled The Pointless Flight from Substance); Ronald Dworkin, The Forum of Principle, 56 N.Y.U. L. REV. 469, 470 (1981) (originally entitled The Flight from Substance, see Commentary, 56 N.Y.U. L. REV. 525, 539 n.* (1981)), reprinted as DwoRkIn, Forum of Principle, supra note 20. Tribe makes both of these critiques, while Dworkin emphasizes the difficulty (in his view the impossibility) of distinguishing substance from process in a principled manner.

107 In A Matter of Dispute, I offer an expanded version of RepresentationReinforcement that I think meets Dworkin's objections (although I don't focus on those objections in particular). The "Dispute-Resolution" account of constitutionalism I articulate there - a type of what I call in the instant article a Procedural account - does not propose a sharp distinction between process and substance, as Dworkin accuses Ely of doing. (See Dworkin, Forum of Principle, supra note 106, at 57-69.) Nor does it assume that democracy is "a precise political concept" (id. at 59) that can be applied by judges without controversy. Quite the contrary: The account I offer supposes that the meaning and content of democracy will be subject to vigorous dispute, dispute that is "substantive" on any realistic view; but it asserts, follow- 
article has been a different one. I've suggested here that Representation-Reinforcement, or some similar type of Procedural account, is the only way to make sense of the legal authority of constitutional rights - or at least a far better way than Substantive justifications, which seem to be the only alternatives currently available.

Procedural justifications of constitutional rights might have other advantages as well. It seems to me, for example, that their burden of persuasion is somewhat less demanding than what the Nuanced Substantive Justification must meet. The Nuanced account must demonstrate that the constitutional process is superior to democratic politics, in all or at least the large majority of the cases in which it applies, as a way of producing morally desirable outcomes. As our engagement with the Aristotelian Difficulty suggests, this will be a pretty tough showing to make, 108 and indeed I think we can read many of the most-trenchant critiques of constitutional rights and judicial review as expressions of deep skepticism in this regard. ${ }^{109}$ Re-

ing Ely, that case-by-case judicial elucidation of constitutionally entrenched norms is a more-acceptable way to resolve or mitigate these disputes than is ordinary democratic politics. See PETERS, supra note 12, at 246-55.

A Matter of Dispute also addresses Tribe's concern that RepresentationReinforcement ignores the American Constitution's many "openly substantive commitments" (Tribe, supra note 106, at 1065 (initial capitalization removed)). Using the example of "substantive due process" - a doctrine that Ely himself rejected, see John Hart Ely, The Wages of Crying Wolf: A Comment on Roe v. Wade, 82 YALE L.J. 920 (1973); ELY, supra note 3, at 14-21 - I suggest in the book that many seemingly "substantive" constitutional commitments can be understood in dispute-resolving, or procedural, terms. See PETERs, supra note 12, at 267-72. (This suggestion can hardly be rejected out of hand by Tribe or Dworkin, both of whom - Dworkin in particular - emphasize the impossibility of extricating questions of "procedure" from questions of "substance." See Tribe, supra note 106, at 1067-72; Dworkin, Forum of Principle, supra note 106, at 57-69.) I acknowledge, however, that not all applications of substantive due process can comfortably be accommodated to a Dispute-Resolution or Procedural account in this way. See PETERs, supra note 12, at 271.

108 See supra Parts III.C.3 and III.C.4.

109 Jeremy Waldron, for example, argues forcefully against the notion that "outcome-related reasons" - reasons hinging on the moral desirability of results - justify a preference for judicial review over majoritarian democracy. See Waldron, Core Case, supra note 38, at 1376-86. Mark Tushnet has written a book-length indictment of the idea that the outcomes generated by judicial review in the United States 
presentation-Reinforcement, on the other hand, needs to demonstrate only that the constitutional process is more fair than democratic politics with respect to certain issues - no simple task, to be sure, but one that seems a bit less Herculean. We might plausibly conclude, for example, that constitutional judges typically are more disinterested than legislators with regard to questions of agency failure, even as we deny that judges possess a special moral wisdom that legislators and their constituents somehow lack. ${ }^{110}$

But the merits of an account as a matter of policy mean very little if that account cannot explain the authority of constitutional rights. Constitutional rights can hardly make the world a better place if those subject to them have no good reason to obey them. A persuasive narrative of legal authority therefore must reside at the heart of any justification of constitutional rights. And without a flight from substance - without, in less abashed terms, the banishment of substance - no narrative of constitutional authority, perhaps no narrative of legal authority more generally, can persuade.

have been morally desirable on the whole. See Mark TUshnet, TAking the CONSTITUTION AWAY FROM THE COURTS (1999).

110 On this point, see PETERS, supra note 12, at 282-86. 